履歴ダンパーを有する制振構造の主架構の塑性化の程度を考慮した エネルギーの釣合に基づく第 1 層の応答予測手法の提案

\title{
ENERGY BALANCE-BASED RESPONSE PREDICTION METHOD FOR FIRST LAYER CONSIDERING DEGREE OF PLASTICITY OF PASSIVE CONTROLLED BUILDING MAINFRAME WITH HYSTERETIC DAMPERS
}

\author{
佐藤大樹*1, 岩森貴 寿 $^{* 2}$, 松澤祐介*3, \\ 北村春幸*4, 山口路夫*5, 脇田直弥*6 \\ Daiki SATO, Takatoshi IWAMORI, Yusuke MATSUZAWA, \\ Haruyuki KITAMURA, Michio YAMAGUCHI and Naoya WAKITA
}

\begin{abstract}
The ideal design of passive controlled building is that its mainframe remains elastic. However, it is necessary to consider the plasticity of its mainframe for there might be occurrences of seismic ground motions that are beyond assumptions. It is essential to evaluate the accumulated damage of damper from several oscillations caused by long-period and longduration ground motions during earthquakes. This paper proposes an energy balance-based response prediction method that considers the extent of plastic deformation of the mainframe with hysteretic dampers. The results from this proposed prediction method corresponds well to those of the time history response analysis.
\end{abstract}

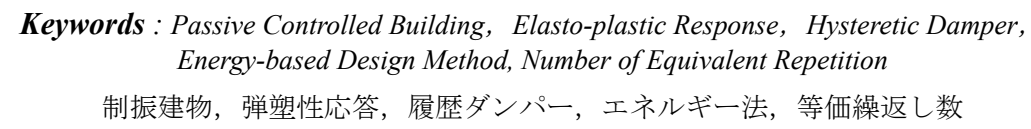

\section{1. はじめに}

1995 年の兵庫県南部地震以降，建物に制振構造を採用する事例が 増加している ${ }^{1)}$ こここで言う制振構造は, 構造骨組の層間変形を利用 し，上下階を結ぶ制振部材によって構造骨組のエネルギーを吸収す る構造形式で，建物重量を支える柱·梁の損傷を低減することにより， 大地震後の建物の継続使用を目標と寸るものである。そのため, 制振 構造は主架構が弾性に留まることを目標に設計されてきたが，近い 将来の襲来が予想される東海・東南海・南海地震など, これまでの想 定をはるかに超える地震動を考えると制振構造においても主架構が 塑性化することを考慮する必要がある。さらに, 履歴ダンパーを有す る制振構造を設計するには, 長周期・長時間地震動やその余震によっ て生じる，多数回の繰返しによるダンパーの累積損傷も評価する必 要がある ${ }^{2), 3)}$

そこで, 耐震構造建物の設計手法の 1 つに, 建物の耐震性を簡便か つ大局的に判断することが可能なエネルギーの釣合に基づく耐震設 計法 ${ }^{4)}$ (以降, エネルギー法と呼ぶ）がある。エネルギー法は従来の 許容応力度や保有耐力による評価ではなく, 地震によるエネルギー
入力と建物が保有するエネルギー吸収能力の対比により評価する。そ のため，早期に降伏する制振部材（以降，ダンパーと呼ぶ）の設計に も適している。例えば，履歴ダンパーを有する制振構造建物を設計す る場合, 2005 年に平成 17 年国土交通省告示第 631 号で規定された 「エネルギーの釣合に基づく耐震計算法」5)を用いると，高さ $60 \mathrm{~m}$ 以 下の建物であれば時刻歴応答解析を必要としない。そのため, 建物の 申請では通常の耐震構造建物と同様に大臣認定が不要となり, 期間を 大幅に短縮することができる ${ }^{6}$ 。

主架構が弾性に留まることを想定した制振構造のエネルギー法は

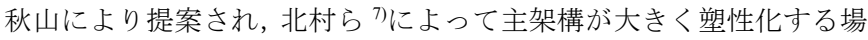
合を考慮したエネルギー法に拡張された。そこでは, 主架構が大きく 塑性化した場合と考えているため, エネルギー配分を決定する重要な 指標となる主架構と, 主架構塑性化時における制振部材の等価繰返し 数を耐震部材の等価繰返し数と同じ値とするとしている。そうするこ とで, 主架構が大きく塑性化した制振構造は耐震構造と同様に評価可 能と考えている。しかし, 制振部材のエネルギー吸収効率は主架構の 塑性化の程度に応じて徐々に低下寸ることが考えられるため ${ }^{8)}$, 主架
*1 東京工業大学未来産業技術研究所 准教授 · 博士 (工学)

*2 東京工業大学大学院環境·社会理工学院 大学院生·修士 (工学)

*3 株山下設計 修士 (工学) (元東京理科大学大学院生)

*4 東京理科大学 副学長·博士 (工学)

*5 新日鉄住金エンジニアリング(株) 博士(工学)

*6 新日鉄住金エンジニアリング(株) 修士(工学)
Assoc. Prof., FIRST, Tokyo Institute of Technology, Dr.Eng.

Grad. Student, School of Environment and Society, Tokyo Institute of Technology, M.Eng.

YAMASHITA SEKKEI INC, MEng.

Vice President, Tokyo University of Science, Dr.Eng.

Nippon Steel \& Sumikin Engineering Co., LTD., Dr.Eng.

Nippon Steel \& Sumikin Engineering Co., LTD., M.Eng. 
構の塑性化の小さい範囲では, 制振部材の等価繰返し数は耐震構造 の等価繰返し数より大きくなることが考えられる。

以上より，本論文では主架構の塑性化の程度を考慮したエネルギ 一の釣合に基づく応答予測手法を提案するとともに，エネルギー法 で重要な指標となる等価繰返し数, 損傷分散係数および主架構の降 伏せん断力が最大応答值に及ぼす影響を検討することを目的とする。 北村らは7), 制振構造の種々のパラメータによる応答特性の変化を第 1 層に代表させている。本論文でもそれを踏襲し, 主架構の塑性化の 程度を考慮した応答予測手法の第 1 弾として, 第 1 層での応答予測 手法および第 1 層での分析結果を示す。

\section{2. 解析モデルおよび入力地震動の概要}

\section{1 主架構と履歴ダンパーの諸元}

本論文では文献 7), 9)を参考に主架構の弾性 1 次固有周期 ${ }_{f 1} T$ を ${ }_{f 1} T=0.5$, $1.0,2.0 \mathrm{~s}$, 質点数 $N$ は $5,10,20$ と設定する。 $f 1 T=0.5 \mathrm{~s}$ は 5 層, $f 1 T=1.0 \mathrm{~s}$ は 10 層, $f 1 T=2.0 \mathrm{~s}$ は 20 層の鋼構造建物の剛性・耐力分布を単純化した多 質点系等価せん断型モデル（以降，せん断モデルと呼ぶ）を用いる。Fig.1 に本論文における解析モデルの概要を示す。質量分布は等分布 $\left(m_{i}=9.8\right.$ $\left.\mathrm{kN} \cdot \mathrm{s}^{2} / \mathrm{cm}\right)$, 主架構の剛性分布 ${ }_{f} k_{i} /{ }_{f} k_{1}$ と主架構の降伏せん断力分布 $f Q_{y i}$ $I_{f} Q_{y 1}$ は台形分布（最上層が最下層の $1 / 2$ ） とする。主架構の初期剛性 ${ }_{f} k_{i}$ は 次式で求められる ${ }^{10)}$

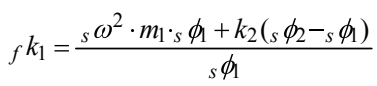

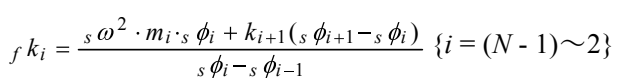

$$
\begin{aligned}
& { }_{f} k_{N}=\frac{{ }_{s} \omega^{2} \cdot m_{N} \cdot s}{\phi_{N}}
\end{aligned}
$$

ここに, ${ }_{s} \omega: s$ 次の固有円振動数, ${ }_{s} \phi_{i}$ : 第 $i$ 層, $s$ 次の固有モード

はじめに, ${ }_{f} k_{i} /{ }_{f} k_{1}$ が台形分布（最上層が最下層の $1 / 2$, Fig.1） と なる任意の剛性を設定し，固有值解析より 1 次の固有モード ${ }_{1} \phi_{i}$ を得 る。その後, 式(1)より ${ }_{1} \omega$ を満足する剛性 ${ }_{f} k_{i}$ を算出する。構造減衰は 主架構の弾性 1 次固有周期 $f 1 T$ に対して ${ }_{f} h=2 \%$ となる剛性比例型と する。 ${ }_{f} Q_{y i} I_{f} Q_{y 1}$ も台形分布（最上層が最下層の $1 / 2$, Fig.1）とする。 ${ }_{f} Q_{y i}$ は次式で求められる。

$$
{ }_{f} Q_{y 1}={ }_{f} \alpha_{y 1}^{\prime} \cdot \sum_{j=1}^{N} m_{j} \cdot g, \quad{ }_{f} Q_{y i}={ }_{f} Q_{y 1} \cdot f \lambda_{i}
$$

ここに, $g$ : 重力加速度, $f \lambda_{i}$ : 第 1 層の主架構の降伏せん断力に対す る第 $i$ 層の主架構の降伏せん断力の比（台形分布）

第 1 層の主架構の降伏せん断力係数 $f \alpha_{y 1}^{\prime}$ を次式で定義する ${ }^{11)}$ 。

$$
\begin{aligned}
& { }_{f} \alpha_{y 1}^{\prime}={ }_{f} \alpha_{y 1} \quad\left({ }_{f 1} T=0.5 \mathrm{~s} \text { の場合 }\right) \\
& { }_{f} \alpha_{y 1}^{\prime}={ }_{f} \alpha_{y 1} /{ }_{f 1} T \quad\left({ }_{f 1} T=1.0,2.0 \mathrm{~s} \text { の場合 }\right)
\end{aligned}
$$

本論文では解析パラメータとして第 1 層の主架構の降伏せん断力係 数 $\alpha_{y 1}$ を設定する。

履歴ダンパー（以降，ダンパーと呼ぶ）は，LY225 級の低降伏点鋼 製の座屈拘束ブレースを階高 $4.2 \mathrm{~m}$ のスパン $6.4 \mathrm{~m}$ に八の字（角度 $54^{\circ}$ ) で取り付けることを想定する。ダンパーの降伏せん断力 ${ }_{d} Q_{y i}$ は 第 1 層のダンパーの降伏せん断力 ${ }_{d} Q_{y 1}$ を基準とし，秋山が提案する 最適降伏せん断力係数分布 $\overline{\alpha_{i}}{ }^{4}$ に基づく降伏せん断力分布 ${ }_{d} Q_{y i} I_{d} Q_{y 1}$

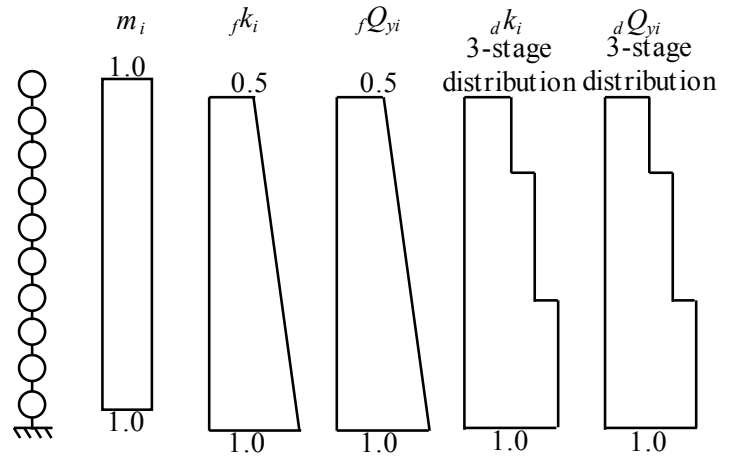

Fig.1 Outline of analysis model (ex. 10DOF)

を 3 つのグループに分割した段階分布とする。ここで， $\overline{\alpha_{i}}$ は $x^{\prime}>0.2$ の場合，次式で表される。

$\overline{\alpha_{i}}=1+1.5927 x^{\prime}-11.8519 x^{\prime 2}$

$+42.5833 x^{\prime 3}-59.4827 x^{\prime 4}+30.1586 x^{\prime 5}$

$x^{\prime}<0.2$ の場合， $\overline{\alpha_{i}}$ は次式で表される。

$\overline{\alpha_{i}}=1+0.5 x^{\prime}$

ここに,

$$
x^{\prime}=\frac{i-1}{N}
$$

10 質点の場合での ${ }_{d} Q_{y i}$ は以下の式で求められる。

$$
\begin{aligned}
& { }_{d} Q_{y i}={ }_{d} \alpha_{y 1}^{\prime} \cdot \overline{\alpha_{1}} \cdot \sum_{j=1}^{N} m_{j} \cdot g \quad(i=1 \sim 4) \\
& { }_{d} Q_{y i}={ }_{d} \alpha_{y 1}^{\prime} \cdot \bar{\alpha}_{5} \cdot \sum_{j=5}^{N} m_{j} \cdot g \quad(i=5 \sim 8) \\
& { }_{d} Q_{y i}={ }_{d} \alpha_{y 1}^{\prime} \cdot \overline{\alpha_{9}} \cdot \sum_{j=9}^{N} m_{j} \cdot g \quad(i=9, \quad 10)
\end{aligned}
$$

第 1 層のダンパーの降伏せん断力係数 $d \alpha_{y 1}^{\prime}$ を次式で定義する ${ }^{12)}$

$$
{ }_{d} \alpha_{y 1}^{\prime}={ }_{d} \alpha_{y 1} /{ }_{f 1} T
$$

本論文では $d \alpha_{y 1}$ をダンパー量と呼び，解析パラメータとして設定す る。ダンパーの降伏層間変形 $d \delta_{y i}$ は全層で一定值とし, $f 1 T$ が $0.5 \mathrm{~s}$ の 場合では $d \delta_{y i}=0.42 \mathrm{~cm}, f 1 T$ が $1.0,2.0 \mathrm{~s}$ の場合では ${ }_{d} \delta_{y i}=0.64 \mathrm{~cm}$ と する9)。ダンパーの初期剛性 ${ }_{d} k_{i}$ は式(6)より求めた ${ }_{d} Q_{y i}$ を用いて次式 より得られる。

$$
{ }_{d} k_{i}={ }_{d} Q_{y i} /{ }_{d} \delta_{y i}
$$

主架構を 1 質点系に置換した場合の等価剛性 $k_{e q}$ を，各層の質量 $m_{i}$ の総和である総質量 $M$ と多質点系モデルの ${ }_{f 1} T$ を用いて, 次式のよう に設定する ${ }^{4)}$ 。

$$
k_{e q}=\frac{4 \pi^{2} \cdot M}{{ }_{f 1} T^{2}}
$$

${ }_{f} k_{i}$ と $k_{e q}$ の比を $\kappa_{i}$ と定義して次式で表す。

$$
\kappa_{i}=\frac{f k_{i}}{k_{e q}}
$$

本論文では Fig.2 に示すように，主架構が弾性である場合と塑性化 する場合の復元力特性を対象とする。塑性化を考慮した主架構とダン パーの復元力特性は完全弾塑性型とする。本論文では, 主架構とダン パーを合わせたものを全体架構と呼ぶ。 


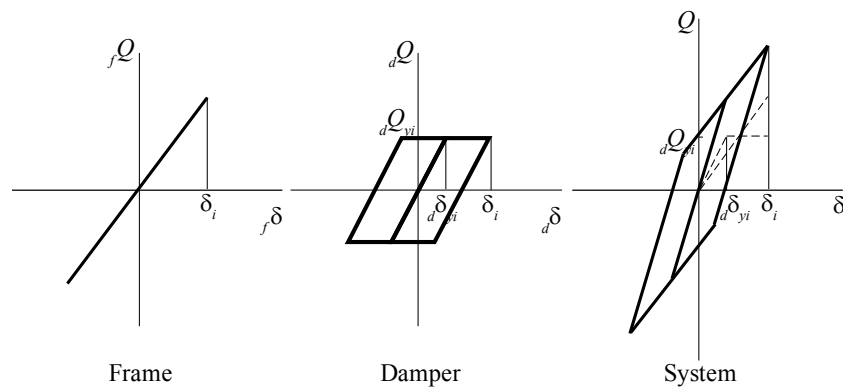

(a) In elastic range of mainframe

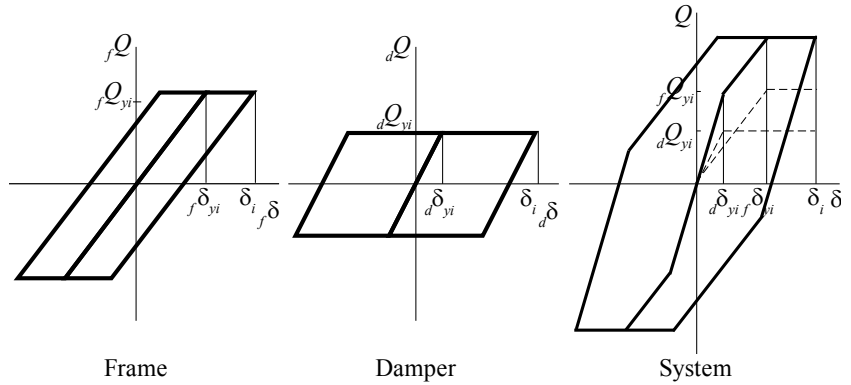

(b) In elasto-plastic range of mainframe

Fig.2 Restoring force characteristic

なお,ダンパーへの変形伝達の障害となる取り付け部材や建物全体 の曲げ変形の影響はないものと仮定し,各層の層間変形は全てダンパ 一の変形に寄与するものとする ${ }^{13)}$ 。

\section{2 入力地震動概要}

検討用地震動は, コーナー周期 $T_{c}=0.64 \mathrm{~s}$ 以降の領域で, 擬似速 度応答スペクトル ${ }_{p} S_{V}$ が一定となる模擬地震動波形 ART HACHI（位 相特性 : HACHINOHE 1968 EW）と ART KOBE（位相特性：JMA KOBE $1995 \mathrm{NS} ）$ を用いる ${ }^{13)}$ 。本論文では入力レベルを変化させ， ${ }_{p} S_{V}=50$, $100,150 \mathrm{~cm} / \mathrm{s}(h=5 \%)$ となる地震動を Level 1, Level 2, Level 3 と位 置付ける。両地震動ともに解析時間刻み $\Delta t=0.01 \mathrm{~s}$ とする。Fig.3 に擬 似速度応答スペクトル ${ }_{p} S_{V}$ とエネルギースペクトル $V_{E}$ （固有周期 $T=$ $0 \sim 3 \mathrm{~s})$ を示す。
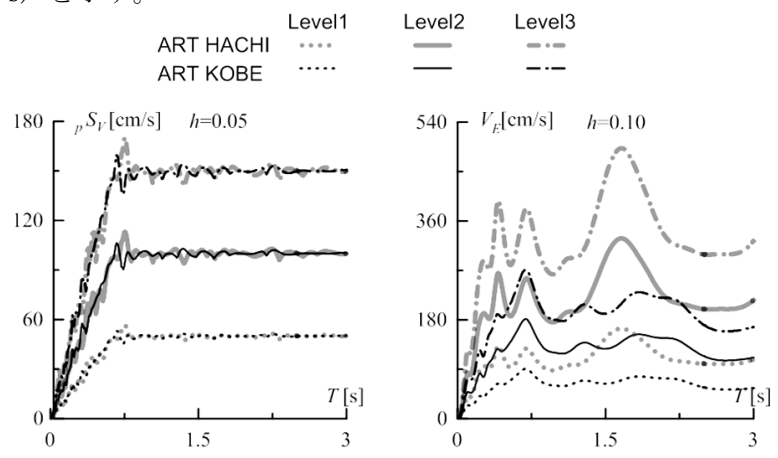

(a) Pseudo velocity response spectrum

(b) Energy spectrum

Fig.3 Response spectrum and energy spectrum

\section{3. 等価繰返し数の評価}

等価繰返し数は部材の塑性化により吸収される累積塑性歪エネル ギーが，最大層間変形の描く等価履歴ループの何ループ分に相当す るかでエネルギー吸収効率を示す指標である。等価繰返し数は入力 される地震動などによって大きくバラっくため, 時刻歷応答解析結
果の下限值の利用が提案されている ${ }^{7)}$ 。北村ら ${ }^{7)}$ は主架構弾性時のダ ンパーの等価繰返し数を 2.5 , 主架構が塑性化する場合で 1.0 を使用 することを提案している。しかし，主架構の塑性化の程度によってダ ンパーのエネルギー吸収効率は変化することが考えられるため ${ }^{8)}$, 北 村らの提案する等価繰返し数では主架構の塑性化の程度が考慮でき ていない7)。そこで, 文献 8)では部材モデルによる主架構の塑性化の 程度を考慮したダンパーの等価繰返し数を分析し, ダンパーのエネル ギー吸収効率は徐々に低下寸る傾向を確認している。本論文では，せ ん断モデルに対する提案式の有用性を検討する。

ダンパーの等価繰返し数 $d n_{i}$ は次式で算出される。

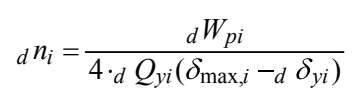

ここに, $\delta_{\max , i}$ : 第 $i$ 層の最大層間変形, ${ }_{d} W_{p i}$ : 第 $i$ 層のダンパーの累 積塑性ひずみエネルギー

次に, 主架構の塑性化に伴うダンパーの等価繰返し数の低下率 $\beta_{n i}$ を次式で定義する。

$$
\beta_{n i}={ }_{d} n_{p i} /{ }_{d} n_{e i}
$$

ここで, ${ }_{d} n_{p i}$ は主架構が塑性化する場合のダンパーの等価繰返し数, ${ }_{d} n_{e i}$ は主架構が弾性の場合のダンパーの等価繰返し数を意味する。主 架構の塑性化の程度を評価する指標となる主架構の塑性変形倍率 ${ }_{f} \mu^{\prime} i$ は次式で算出される。

$$
f \mu_{i}^{\prime}=\frac{\delta_{\max , i}}{{ }_{d} \delta_{y i}}-1
$$

北村ら ${ }^{7)}$ の提案では，いずれの $f \mu_{i}^{\prime}$ でも $\beta_{n i}$ は 0.4 であることを意味 する。本論文において $\beta_{n i}$ は主架構の塑性化の程度に応じて徐々に低 下し,$f \mu_{i}^{\prime}=3$ 程度から 0.4 に収束するとし， $\beta_{n i}$ と ${ }_{f} \mu_{i}^{\prime}$ の関係式である 次式を提案する ${ }^{8)}$

$$
\left.\begin{array}{ll}
\beta_{n i}=-0.2_{f} \mu_{i}^{\prime}+1 & f \mu_{i}^{\prime}<3 \\
\beta_{n i}=0.4 & f \mu_{i}^{\prime} \geq 3
\end{array}\right\}
$$

Fig.4に $\beta_{n i}$ を縦軸とし, 横軸を $f \mu_{i}^{\prime}$ としたときの時刻歴応答解析結 果を示す。時刻歴応答解析結果は前述したせん断モデル（Fig.1）の結 果と文献 8)の部材モデルによる解析結果を示す。また, せん断モデル の解析結果は, 最大損傷集中 $\left[1 / d \gamma_{i}\right]_{c, \text { max }}$ に質点数 $N$ を乗じた值が 2 以 上となるケースは過度な損傷集中が生じているため, その結果は除外 している ${ }^{14)}$ 。Fig.4 より, 式(14)はダンパーの等価繰返し数が低下寸る 傾向を部材モデルとせん断モデルの両方ともに概ね捉えられている ことが確認できる。

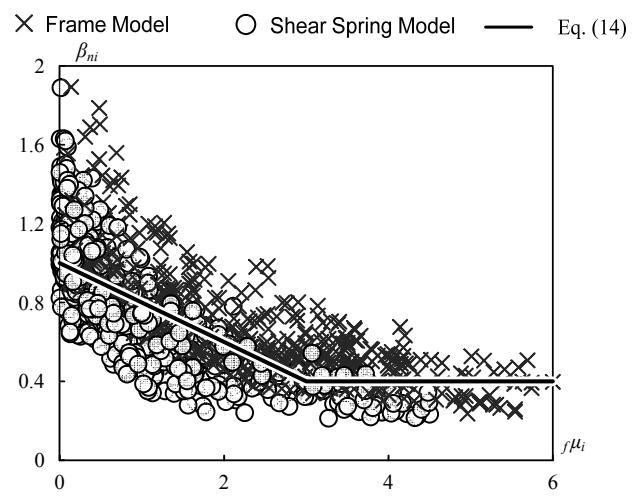

Fig.4 Reduction rates of the number of equivalent repetitions 


\section{4. 主架構弾性時と塑性化する場合を考慮したエネルギー法}

\section{1 エネルギーの釣合式}

制振構造のエネルギー時刻歴の模式図を Fig.5 に示す。横軸は地動 開始からの時間 $t$ を表し, $t_{m}$ は建物の最大応答值発生時間で, $t_{0}$ は地 動の継続時間を表す。 ${ }_{f} W_{e},{ }_{f} W_{h},{ }_{f} W_{p}$ は主架構の弾性振動エネルギー, 減衰により消費されるエネルギーおよび累積塑性ひずみエネルギー であり， $d_{d} W_{e}, d W_{p}$ はダンパーの弾性振動エネルギーおよび累積塑性 ひずみエネルギーである。次式に $t=t_{m}$ の場合でのエネルギーの釣合 式を示す。

${ }_{f} W_{e}\left(t_{m}\right)+{ }_{d} W_{e}\left(t_{m}\right)+{ }_{f} W_{h}\left(t_{m}\right)+{ }_{f} W_{p}\left(t_{m}\right)+{ }_{d} W_{p}\left(t_{m}\right)=E\left(t_{m}\right)$

ここに, $E:$ 入力エネルギー

$E$ は ${ }_{f} W_{h}$ を用いて次式で表される。

$E_{D}(t)=E(t)-{ }_{f} W_{h}(t)$

ここに， $E_{D}:$ 構造体の損傷に寄与寸るエネルギー4)

Fig.5 のように塑性化の程度の大きな構造体や制振部材を付加した 建物では一般的に $E\left(t_{m}\right) \leq E\left(t_{0}\right)$ となることから ${ }^{4)}, E\left(t_{m}\right)$ を $E\left(t_{0}\right)$ に置 き換え，式(16)を代入すると， $t=t_{m}$ の場合でのエネルギーの釣合式は 次式で表すことができる。

${ }_{f} W_{e}\left(t_{m}\right)+_{d} W_{e}\left(t_{m}\right)+{ }_{f} W_{p}\left(t_{m}\right)+_{d} W_{p}\left(t_{m}\right)=E_{D}\left(t_{0}\right)$

${ }_{f} W_{e}, d W_{e}$ は $t=t_{m}$ において最大值となり, $t=t_{0}$ ではほとんど消滅 する。 $t=t_{0}$ の場合での釣合式を次式に示す。

$$
{ }_{f} W_{p}\left(t_{0}\right){ }_{d} W_{p}\left(t_{0}\right)=E_{D}\left(t_{0}\right)
$$

最大層間変形 $\delta_{\max , i}$ などの最大值を算出するときは最大応答発生時 間 $t_{m}$ における釣合式（式(17)）から，主架構の累積塑性変形倍率 ${ }_{f} \eta_{i}$ などの累積值を算出するときは地震終了時間 $t_{0}$ における釣合式（式 (18)）から求める。

$E_{D}$ の速度換算値 $V_{D}$ を，運動エネルギー式である次式で算出する。 $V_{D}=\sqrt{2 E_{D} / M}$

非制振弾性モデルの最大せん断力係数 $f \alpha_{0}$ と最大変形 $f \delta_{0}$ は, $V_{D}$ と 主架構の弾性 1 次固有周期 $f 1 T$ を用いて次式で算出できる ${ }^{6)}$

${ }_{f} \alpha_{0}=\frac{2 \pi \cdot V_{D}}{{ }_{f 1} T \cdot g}, \quad{ }_{f} \delta_{0}=\frac{{ }_{f 1} T \cdot V_{D}}{2 \pi}$

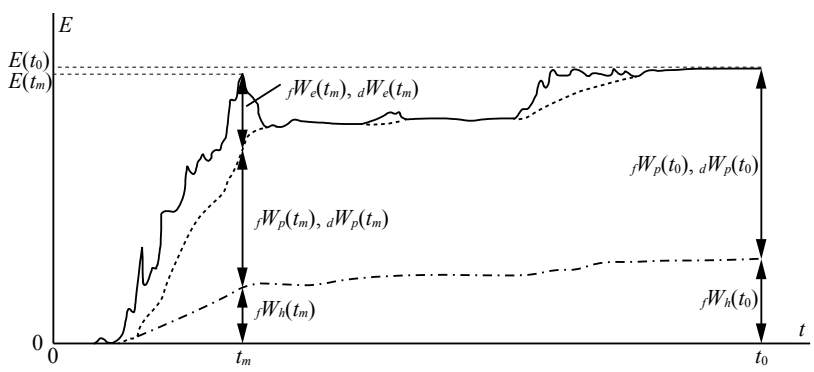

Fig.5 Schematic diagram of the time history of energy

\section{2 主架構弾性時のエネルギーの算出方法 ${ }^{6}$}

本節では，主架構が弾性の場合でのエネルギーの釣合式を導出す る。弾性振動エネルギーは, ダンパーの弾性振動エネルギーを無視し $\left({ }_{d} W_{e}=0\right)$, 主架構の弾性振動エネルギー ${ }_{f} W_{e}$ のみで表される (式(22))。 ${ }_{f} W_{e}\left(t_{m}\right)=\sum_{i=1}^{N}{ }_{f} W_{e i}=\sum_{i=1}^{N} \frac{{ }_{f} Q_{\max , i} \cdot \delta_{\max , i}}{2} \cong \frac{1}{2} \frac{M \cdot g^{2} \cdot f 1 T^{2}}{4 \pi^{2}} \cdot f \alpha_{1}^{2}$

$t=t_{m}$ ときのダンパーの累積塑性ひずみエネルギー ${ }_{d} W_{p}$ は，最大変 形 $\delta$ max,$i$ の定振幅で消費するダンパーの累積塑性ひずみエネルギーと
主架構弾性時のダンパーの等価繰返し数 ${ }_{d} n_{e i}$ の積で表される。

$$
{ }_{d} W_{p}\left(t_{m}\right)={ }_{d} \gamma_{i} \cdot d W_{p i}=4_{d} n_{e i} \cdot \frac{M \cdot g^{2} \cdot f 1 T^{2}}{4 \pi^{2}} \cdot d \gamma_{i} \cdot c_{i} \cdot d \alpha_{y i} \cdot f \alpha_{i}
$$
ここに

$c_{i}=\left(\sum_{j=i}^{N} \frac{m_{j}}{M}\right)^{2} \cdot \frac{1}{\kappa_{i}}$

\section{3 主架構弾性時の第 1 層の応答予測式の導出 ${ }^{6)}$}

主架構弾性時ではダンパー弾性振動エネルギーを無視し, 式(17)に 式(22)，(23)を代入すると次式が得られる。

$$
\frac{1}{2} \cdot \frac{M \cdot g^{2} \cdot f 1 T^{2}}{4 \pi^{2}}{ }_{f} \alpha_{1}^{2}+4_{d} n_{e i} \frac{M \cdot g^{2} \cdot f 1 T^{2}}{4 \pi^{2}} d \gamma_{i} \cdot c_{i} \cdot d \alpha_{y i} \cdot f \alpha_{i}=E_{D}
$$

損傷に寄与する入力エネルギーE $E_{D}$ は式(19)，(20)を用いて，次式で 算出される。

$$
E_{D}=\frac{M V_{D}^{2}}{2}=\frac{M}{2}\left(\frac{f \alpha_{0} \cdot f 1 T \cdot g}{2 \pi}\right)^{2}
$$

式(25)に式(26)を代入すると次式が得られる。

${ }_{f} \alpha_{1}^{2}+8_{d} n_{e i} \cdot d \gamma_{i} \cdot c_{i} \cdot d \alpha_{y i} \cdot f \alpha_{i}=f \alpha_{0}^{2}$

両辺を ${ }_{f} \alpha_{0}$ で除すことで，次式が得られる。

$\frac{{ }_{f} \alpha_{1}^{2}}{{ }_{f} \alpha_{0}^{2}}+8_{d} n_{e i} \cdot d \gamma_{i} \cdot c_{i} \cdot \frac{d \alpha_{y i} \cdot f \alpha_{i}}{f_{f}^{2}}=1$

$i=1$ とし, ${ }_{f} \alpha_{1} /{ }_{f} \alpha_{0}$ について解の公式で解くと次式が得られる。

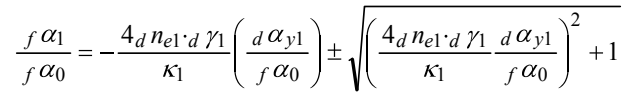

以上より, 主架構が弾性である場合の非制振弾性モデルのせん断力 係数に対する第 1 層の主架構, ダンパーのせん断力係数の割合 ${ }_{f} \alpha_{1} /{ }_{f} \alpha_{0}, d \alpha_{y 1} / f \alpha_{0}$ と, 非制振弹性モデルの応答変形に対する第 1 層 の最大層間変形の割合 $\kappa_{1} \cdot \delta_{\max , 1} /{ }_{f} \delta_{0}$ の関係はそれぞれ式(30), (31)で 表され，全体架構のせん断力係数は式(32)で表される。

$\left(\kappa_{1} \frac{\delta_{\max , 1}}{f \delta_{0}}\right)=\left(\frac{f \alpha_{1}}{f \alpha_{0}}\right)$

$\left(\kappa_{1} \frac{\delta_{\max , 1}}{f} \delta_{0}\right)=-\frac{4_{d} n_{e 1} \cdot d \gamma_{1}}{\kappa_{1}}\left(\frac{d \alpha_{y 1}}{f \alpha_{0}}\right) \pm \sqrt{\left(\frac{4_{d} n_{e 1} \cdot d \gamma_{1}}{\kappa_{1}}\right)^{2}\left(\frac{d \alpha_{y 1}}{f \alpha_{0}}\right)^{2}+1}$

$\left(\frac{\alpha_{1}}{{ }_{f} \alpha_{0}}\right)=\left(\frac{{ }_{d} \alpha_{y 1}}{{ }_{f} \alpha_{0}}\right)+\left(\frac{f \alpha_{1}}{{ }_{f} \alpha_{0}}\right)$

\section{4 主架構が塑性化する場合でのエネルギーの算出方法}

本節では, 主架構が塑性化する場合でのエネルギーの釣合式を導出 する。前節と同様に，ダンパーの弾性振動エネルギーを無視する $\left({ }_{d} W_{e}=0\right)$ 。主架構の弾性振動エネルギー ${ }_{f} W_{e}$ は次式で求められる。

$$
{ }_{f} W_{e}\left(t_{m}\right)=\sum_{i=1}^{N}{ }_{f} W_{e i}=\sum_{i=1}^{N} \frac{f Q_{y i} \cdot f \delta_{y i}}{2} \cong \frac{1}{2} \frac{M \cdot g^{2} \cdot{ }_{f 1} T^{2}}{4 \pi^{2}} \cdot{ }_{f} \alpha_{y 1}^{2}
$$

全ダンパーの累積塑性ひずみエネルギー ${ }_{d} W_{p}\left(t_{m}\right)$ は, 最大変形 $\delta$ max, の定振幅で消費するダンパーの累積塑性ひずみエネルギーと主架構 が塑性化する場合のダンパーの等価繰返し数 ${ }_{d} n_{p i}$ の積で表される。

${ }_{d} W_{p}\left(t_{m}\right)=4_{d} n_{p i} \cdot d \gamma_{i} \cdot d \alpha_{y i} \cdot \sum_{j=i}^{N} m_{j} \cdot g \cdot \delta_{\text {max }, i}$

主架構の全累積塑性ひずみエネルギー ${ }_{f} W_{p}$ は，第 $i$ 層の主架構の累 
積塑性ひずみエネルギー ${ }_{f} W_{p i}$ と主架構の損傷分散係数 ${ }_{f} \gamma_{i}$ を用いて表 される。 $t=t_{m}$ のときの ${ }_{f} W_{p}$ は, 主架構の降伏せん断力 ${ }_{f} Q_{y i}$ 之最大変 形 $\delta_{\text {max }, i}$ の 1 ループが消費する累積塑性ひずみエネルギーと主架構の 等価繰返し数 $f n_{i}$ の積で表される(式(35))。

$$
{ }_{f} W_{p}\left(t_{m}\right)={ }_{f} \gamma_{i} \cdot f W_{p i}=4_{f} n_{i} \cdot f \gamma_{i} \cdot f Q_{y i}\left(\delta_{\max , i}-f \delta_{y i}\right)
$$

\section{5 主架構の塑性化の程度を考慮した第 1 層の応答予測式の導出}

主架構の塑性化の程度を考慮する場合でのダンパーの累積塑性ひ ずタエネルギー ${ }_{d} W_{p}$ は式(34)ではなく, 主架構弾性時の式(23)のダン パーの等価繰返し数 $d n_{e i}$ に主架構の塑性化に伴う等価繰返し数の低 下率 $\beta_{n i}$ を乗じた次式で求めることができる。

$$
{ }_{d} W_{p}\left(t_{m}\right)=4_{d} n_{e i} \cdot \beta_{n i} \cdot d \gamma_{i} \cdot d \alpha_{y i} \sum_{j=i}^{N} m_{j} \cdot g \cdot \delta_{\max , i}
$$

以上より, ダンパーの弾性振動エネルギーを無視し, 式(17)に式(33), (35), (36)を代入すると次式が得られる。

$$
\begin{aligned}
\frac{1}{2} \frac{M \cdot g^{2} \cdot f 1 T^{2}}{4 \pi^{2}} f & \alpha_{y 1}^{2}+4_{d} n_{e i} \cdot \beta_{n i} \cdot d \gamma_{i} \cdot d \alpha_{y i} \sum_{j=i}^{N} m_{j} \cdot g \cdot \delta_{\max , i} \\
& +4_{f} n_{i} \cdot f \gamma_{i} \sum_{j=i}^{N} m_{j} \cdot g \cdot f \alpha_{y i}\left(\delta_{\max , i}-f_{f} \delta_{y i}\right)=E_{D}
\end{aligned}
$$

式(37)に，式(29)を代入すると次式が得られる。

$$
\begin{aligned}
f & \alpha_{y 1}^{2}+ \\
& 8_{d} n_{e i} \cdot \beta_{n i} \cdot d \gamma_{i}\left(\frac{2 \pi}{f 1 T \cdot g}\right)^{2} d \alpha_{y i} \cdot g \cdot \delta_{\max , i} \\
& +8_{f} n_{i} \cdot f \gamma_{i}\left(\frac{2 \pi}{{ }_{f 1} T \cdot g}\right)^{2} f \alpha_{y i} \cdot g\left(\delta_{\max , i}-f_{f} \delta_{y i}\right)={ }_{f} \alpha_{0}^{2}
\end{aligned}
$$

両辺を ${ }_{f} \alpha_{0}$ で除すことで, 次式が得られる。

$$
\begin{aligned}
\left(\frac{f \alpha_{y 1}}{f \alpha_{0}}\right)^{2}+8_{d} n_{e i} \cdot \beta_{n 1} \cdot d \gamma_{i} \cdot\left(\frac{d \alpha_{y i}}{f \alpha_{0}}\right) \cdot\left(\frac{\delta_{\max , i}}{f^{\delta}}\right) & \\
& +8_{f} n_{i} \cdot f \gamma_{i}\left(\frac{f \alpha_{y i}}{f \alpha_{0}}\right) \cdot \frac{\delta_{\max , i}-f \delta_{y i}}{{ }_{f} \delta_{0}}=1
\end{aligned}
$$

$i=1$ とし， $\delta_{\max , 1 / f} \delta_{0}$ について解くと次式が得られる。

$$
\left(\frac{\delta_{\max , 1}}{{ }_{f} \delta_{0}}\right)=\frac{\left(\frac{{ }_{f} \alpha_{0}}{f \alpha_{y 1}}\right)-\left(\frac{f \alpha_{y 1}}{f \alpha_{0}}\right)+8_{f} n_{1} \cdot f \gamma_{1} \frac{1}{f \kappa_{i}}\left(\frac{f \alpha_{y 1}}{f \alpha_{0}}\right)}{8 \cdot d n_{e 1} \cdot \beta_{n 1} \cdot d \gamma_{1}\left(\frac{d \alpha_{y 1}}{f \alpha_{0}}\right)\left(\frac{f \alpha_{0}}{f \alpha_{y 1}}\right)+8_{f} n_{1} \cdot f \gamma_{1}}
$$

以上より，主架構の塑性化の程度を考慮した非制振弾性モデルの 応答変形に対する第 1 層の最大層間変形の割合 $\kappa_{1} \cdot \delta_{\max 1} / f_{f} \delta_{0}$ の関係は 次式で表すことができる。

$$
\left(\kappa_{1} \frac{\delta_{\text {max }, 1}}{f \delta_{0}}\right)^{(j+1)}=\frac{\kappa_{1}\left(\frac{f \alpha_{0}}{f f \alpha_{y 1}}\right)-\kappa_{1}\left(\frac{f \alpha_{y 1}}{f \alpha_{0}}\right)+8_{f} n_{1} \cdot f \gamma_{1}\left(\frac{f \alpha_{y 1}}{f \alpha_{0}}\right)}{8 \cdot d n_{e 1} \cdot \beta_{n 1}{ }^{(j)} \cdot d \gamma_{1}\left(\frac{d \alpha_{y 1}}{f \alpha_{0}}\right)\left(\frac{f \alpha_{0}}{f \alpha_{y 1}}\right)+8_{f} n_{1} \cdot f \gamma_{1}}
$$

ここで, 括弧書きの添え字は反復操作回数である。右辺の $\beta_{n 1}^{(j)}$ は, $\delta_{\text {max }, 1}^{(j)}$ を含む項であるため, 左辺の $\delta_{\text {max }, 1}{ }^{(j+1)}$ と值を一致させる必要が ある。そこで, はじめは $\beta_{n 1}{ }^{(1)}=1$ と仮定し $\delta_{\max , 1^{(2)}}$ を求め, $\delta_{\text {max }, 1}{ }^{(j+1)}$ が概 永一定值となるまで式(41)に代入する。筆者らは収斂計算を 5 回程度 行うことで $\delta_{\max , 1},^{(j)}$ と $\delta_{\max , 1},^{(j-1)}$ の誤差が $10 \%$ 以下に収まることを確認し ている。詳しくは附録 A を参照されたい。

\section{5. 主架構の塑性化の程度を考慮した応答予測手法の妥当性の検討}

本章では，前章で定義したエネルギー法による応答予測（以降，応
答予測）と時刻歴応答解析結果（以降, 解析結果）を比較し, エネル ギー法の妥当性について検討する。応答予測手順は附録 B を参照さ れたい。なお，本章では紙面の都合上 ART HACHI の結果のみ示す。

\section{1 主架構の塑性化の程度を考慮した応答予測と解析結果}

本節では, 4 章で定義した第 1 層のせん断力係数と最大層間変形の 関係 (式(30) (32), 式(41)) を用いて, 制振構造の主架構弾性の場合, 主架構が塑性化する場合の第 1 層の応答曲線を示す。はじめに, 各モ デルの主架構の弾性 1 次固有周期 $f 1 T$ とそれに対応する構造体の損傷に 寄与するエネルギーの速度換算值 $V_{D}$ を用いて式(20)より非制振弾性 モデルのせん断力係数 ${ }_{f} \alpha_{0}$ を算出する。制振構造の第 1 層のせん断力 係数と最大層間変形の関係は, ダンパー量 $d \alpha_{y 1}$ を ${ }_{f} \alpha_{0}$ で除したダンパ 一の降伏せん断力係数比 ${ }_{d} \alpha_{y 1} /_{f} \alpha_{0}$ を用いて式(31)から主架構弾性時, 式(41)から主架構の塑性化した場合での, 非制振弾性モデルの変形に 対寸る第 1 層の最大層間変形の割合 $\kappa_{1} \cdot \delta_{\max , 1} /_{f} \delta_{0}$ （以降，最大層間変 形比と呼ぶ）をそれぞれ算出する。なお，損傷分散係数，等価繰返し 数および非制振弾性モデルのせん断力係数に対する主架構の降伏せ ん断力係数の変動による応答予測に及ぼす影響については 6 章にて 後述する。

Fig.6 の縦軸に全体架構のせん断力係数比 $\alpha_{1} / f \alpha_{0}$, 主架構のせん断 力係数比 ${ }_{f} \alpha_{1} /{ }_{f} \alpha_{0}$, ダンパーの降伏せん断力係数比 ${ }_{d} \alpha_{y 1} /{ }_{f} \alpha_{0}$ とし, 横軸に最大層間変形比 $\kappa_{1} \cdot \delta_{\max , 1} /_{f} \delta_{0}$ とした応答曲線を示す。ここで, エネルギー法の応答曲線を描く際に用いる主架構の損傷分散係数 $f \gamma_{1}$ と等価繰返し数 $f n_{1}$ は $f \gamma_{1}=4.0, f n_{1}=1.0$ に設定し, ダンパーの損傷 分散係数 $d \gamma_{1}$ と主架構弾性時のダンパー等価繰返し数 ${ }_{d} n_{e 1}$ は ${ }_{d} \gamma_{1}=5.0$, ${ }_{d} n_{e 1}=2.5$ に設定する。解析モデルは 2 章で前述した, 10 質点系等価 せん断型モデルを採用し, ダンパー量 $d \alpha_{y 1}$ および入力レベルを自由に 変動させ, 解析結果が $1.0<{ }_{d} n_{e 1}<7.5,4.0<_{d} \gamma_{1}<8.0$ となる場合の結 果を示す。なお, 主架構が塑性化する場合には $0.19<_{f} \alpha_{y 1} /{ }_{f} \alpha_{0}<0.21$ となる解析結果を選択している。Fig.6 より, 主架構弾性時と主架構

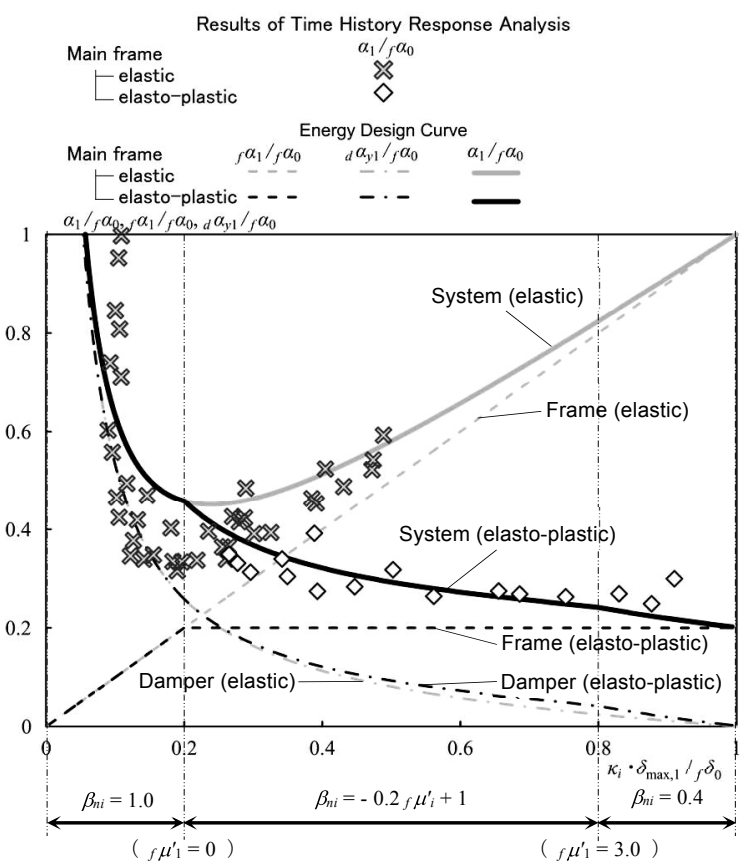

Fig.6 Comparison of response evaluation of first story ART HACHI $, \boldsymbol{N}=\mathbf{1 0},{ }_{f 1} T=\mathbf{1 . 0}$

${ }_{f} \alpha_{y 1} /{ }_{f} \alpha_{0}=0.2, \quad{ }_{d} n_{e 1}=2.5, \quad d \gamma_{1}=5.0,{ }_{f} n_{1}=1.0, \quad f \gamma_{1}=4.0$ 
弾塑性時の応答曲線は主架構が塑性化する範囲となる $\kappa_{1} \cdot \delta_{\max , 1} /{ }_{f} \delta$ が 0.2 以降で異なることがわかる。また， $\kappa_{1} \cdot \delta_{\max , 1} /_{f} \delta_{0}=0.8$ で応答曲 線に折れ点が確認できる。これは, $f \mu_{i}^{\prime}=3$ にあたり式(41)の $\beta_{n i}$ が式 (14a)から式(14b)になるためである。主架構が弾性, 塑性化にかかわ らず解析結果より得られる $\alpha_{1} / f \alpha_{0}(\times, \diamond)$ は応答曲線とよい対応を 示すことがわかる。解析結果のバラつきは応答曲線が $d n_{e 1}, d \gamma_{1}$ など のパラメータに一定值を用いているのに対して, 解析結果は上述し た範囲でのバラつきを有するためである。 $d n_{e 1}, \quad d \eta_{\text {および } f} \alpha_{y 1} / f \alpha_{0}$ の值による影響については次章にて後述する。本論文では, 制振構造 を対象としているが，耐震構造の応答曲線も附録 C で示す。

\section{2 主架構の塑性化の程度を考慮した応答予測手法の精度}

Fig.7 に第 1 層の応答予測の精度を示す。横軸は解析結果による第 1 層の最大層間変形角 $\left[R_{\max , 1}\right]_{c}$ とし, 縦軸は応答予測による第 1 層の 最大層間変形角 $\left[R_{\text {max }, 1}\right]_{p}$ とする。図中の点線は誤差 $10 \%$ を意味する。 なお，応答予測による最大層間変形比 $\kappa_{1} \cdot \delta_{\max , 1} /_{f} \delta_{0}$ は $\kappa_{1} \cdot \delta_{\max , 1} l_{f} \delta_{0} \leqq$ ${ }_{f} \alpha_{1} / f_{f} \alpha_{0}$ の範囲を式(31)で求め, $\kappa_{1} \cdot \delta_{\max , 1} /{ }_{f} \delta_{0}>_{f} \alpha_{1} /_{f} \alpha_{0}$ の範囲を式 (41)で求めており, 主架構の損傷分散係数 $f \gamma_{1}$, 主架構の等価繰返し数 ${ }_{f} n_{1}$, ダンパーの損傷分散係数 $d \gamma_{1}$, 主架構弾性時のダンパー等価繰返 し数 ${ }_{d} n_{e 1}$ および損傷に寄与する入力エネルギーの速度換算值 $V_{D}$ は解 析結果を用いることとする。 $R_{\max , 1}$ は最大層間変形 $\delta_{\max , 1}$ に階高 $4.2 \mathrm{~m}$ を除して算出される。

Fig.7 より，応答予測は $R_{\max , 1}$ が大きくなるにつれて精度が高くな る傾向がわかる。 $R_{\text {max }, 1}$ が小さい範囲においても概社精度良く対応し ているが, 主架構の塑性化の程度が小さい範囲では応答予測が解析 結果に対して小さくなることが確認できる。紙面の都合により，ここ では ART HACHI 入力時の解析ケースのみを示しているが， ART KOBE や観測波 El Centro 1940 NS の地震動でも同様の傾向が得られ ることを確認している。

\section{6. パラメータの違いが第 1 層の応答に及ぼす影響}

前章では, 主架構の損傷分散係数 $f \gamma_{1}$, 主架構の等価繰返し数 $f n_{1}$, ダンパーの損傷分散係数 $d \gamma_{1}$, 主架構弾性時のダンパー等価繰返し数 ${ }_{d} n_{e l}$, 主架構の降伏せん断力係数比 ${ }_{f} \alpha_{y 1} / \alpha_{f} \alpha_{0}$ および構造体の損傷に寄 与寸るエネルギーの速度換算值 $V_{D}$ は解析結果を用いていた。エネル ギー法で応答を予測する際は，特に $f \gamma_{1},{ }_{f} n_{1}, d \gamma_{1}, d n_{e 1}$ および, ${ }_{f} \alpha_{y 1}$ $I_{f} \alpha_{0}$ の設定が重要となる。本章では, 10 質点系のせん断モデルを用 いて設定するパラメータ $\left({ }_{f} \alpha_{y 1} / f \alpha_{0},{ }_{f} n_{1}, d n_{e 1}, f \gamma_{1}, d \gamma_{1}\right)$ の違いによ
る第 1 層のせん断力係数と最大層間変形の関係を分析する。

\section{1 制振構造の第 1 層の応答曲線}

Fig. 8 に第 1 層の応答曲線を示す。応答曲線を算出する際の主架構 の損傷分散係数を $f \gamma_{1}=4.0$, ダンパーの損傷分散係数を $d \gamma_{1}=5.0$ と設 定し, 主架構の等価繰返し数 $f n_{1}=1.0$, 主架構弾性時のダンパーの等

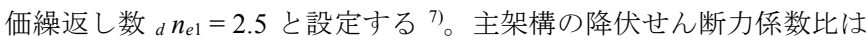
${ }_{f} \alpha_{y 1} /{ }_{f} \alpha_{0}=0.2$ と設定する。これは, 次節より変動させる係数の平均 的な值である。このとき，主架構が弾性範囲 $\left(\kappa_{1} \cdot \delta_{\max , 1} l_{f} \delta_{0}<0.2\right)$ は 式(31), 主架構が塑性化する範囲 $\left(\kappa_{1} \cdot \delta_{\max , 1} /{ }_{f} \delta_{0}>0.2\right)$ は式(41)で示 している。本論文では, 質点系による解析精度を担保する意味から, 主架構の塑性変形倍率 ${ }_{f} \mu_{i}^{\prime}$ が 1.0 以内であることが望ましいと考え,

Fig.8 以降の図において, 主架構弾塑性時で ${ }_{f} \mu_{i}^{\prime}$ が 1.0 となる ${ }_{f} \alpha_{1} /{ }_{f} \alpha_{0}$

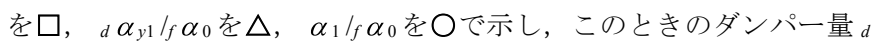
$\alpha_{y 1}$ が同じ場合での主架構弾性時の ${ }_{f} \alpha_{y 1} / f \alpha_{0}$ を,${ }_{d} \alpha_{y 1} /{ }_{f} \alpha_{0}$ を $\mathbf{\Delta}, \alpha$ ${ }_{1} /{ }_{f} \alpha_{0}$ を○です。

Fig. 8 の縦軸に着目すると, 主架構が塑性化することで $\alpha_{1} /{ }_{f} \alpha_{0}$ が大 幅に低下している $(\bullet \rightarrow O)$ 。次に, Fig.8 の横軸に着目すると, 同じ ${ }_{d} \alpha_{y 1}$ の場合で主架構弾性時と主架構弾塑性時の $\kappa_{1} \cdot \delta_{\max , 1} / \delta_{f} \delta_{0}$ がほと んど変化しないことが確認できる。これは, 主架構の塑性化によりダ ンパーの等価繰返し数が 2 割低下し (式(14), $\left.f \mu_{i}^{\prime}=1.0\right)$, ダンパーに よるエネルギー吸収量が低下するが, 主架構の塑性化によるエネルギ 一吸収で，それを補っているためである。ただし， $f \gamma_{1}, f n_{1}$ の值によ って異なるため最大応答を評価する際には注意が必要である。

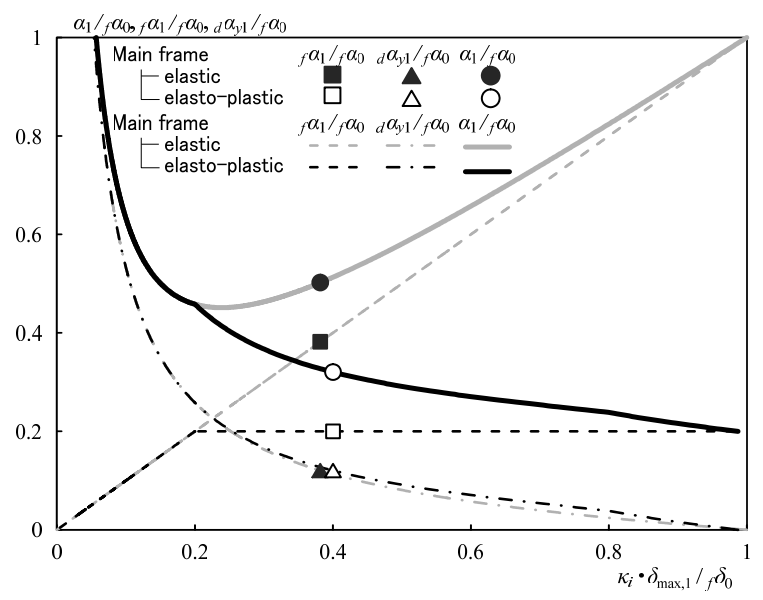

Fig.8 Response curve of the first story

${ }_{f} \alpha_{y 1} /{ }_{f} \alpha_{0}=0.2,{ }_{d} n_{e 1}=2.5,{ }_{d} \gamma_{1}=5.0,{ }_{f} n_{1}=1.0,{ }_{f} \gamma_{1}=4.0$
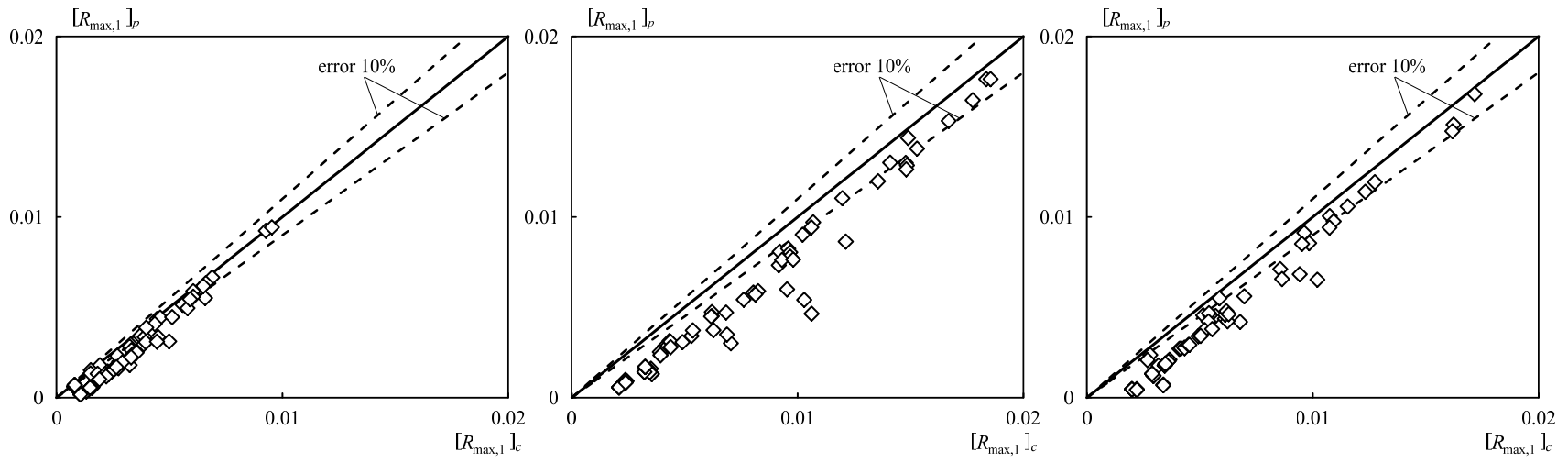

(b) $N=10,{ }_{f 1} T=1.0$

(c) $N=20,{ }_{f 1} T=2.0$

Fig.7 Accuracy of response prediction (ART HACHI) 


\section{2 主架構の降伏せん断力係数比が応答に及ぼす影響}

本節では, 主架構の降伏せん断力係数比 ${ }_{f} \alpha_{y 1} /{ }_{f} \alpha_{0}$ を $0.1,0.3$ に変動 させる。これは, 主架構が塑性化しない非制振構造に対して推定され る最大せん断力の 1 割および 3 割のせん断力で主架構が塑性化する ことを意味する。

Fig.9 に ${ }_{f} \alpha_{y 1} /{ }_{f} \alpha_{0}$ を変動させた第 1 層の応答曲線を示す。なお, Fig.9(a)の ${ }_{f} \alpha_{y 1} /{ }_{f} \alpha_{0}=0.1$ のき（図中口）, ダンパーの降伏せん断力係 数比 $d \alpha_{y 1} /{ }_{f} \alpha_{0}$ が 0.3 程度（図中 $\triangle ）$ となっており，ダンパーより主架 構の降伏せん断力が低いため制振構造の設計として望ましくない例 である。Fig.9(a)の ${ }_{f} \alpha_{y 1} /{ }_{f} \alpha_{0}=0.1$ では，主架構が塑性化すると主架構 弾性時より変形が大きくなる。一方, Fig.9(b) の ${ }_{f} \alpha_{y 1} / f \alpha_{0}=0.3$ では, 主架構弾性時よりも主架構が塑性化する場合の方が最大層間変形比 $\kappa_{1} \cdot \delta_{\max , 1} /_{f} \delta_{0}$ が小さくなることがわかる $\rightarrow \bigcirc) 。{ }_{d} \alpha_{y 1} / f \alpha_{0}$ のプロ ットに着目すると, Fig.9(a)では ${ }_{d} \alpha_{y 1} /{ }_{f} \alpha_{0}$ が 0.3 程度であるのに対し て, Fig.9(b)では ${ }_{d} \alpha_{y 1} /{ }_{f} \alpha_{0}$ が 0.05 程度であることが確認できる。従っ て $f_{f} \alpha_{y 1} /{ }_{f} \alpha_{0}$ を大きく設定すると主架構のエネルギー吸収効率が良く なり，少ないダンパー量 $d \alpha_{y 1}$ で変形を抑えられることがわかる。た だし，この結果は主架構の等価繰返し数 ${ } n_{1}=1.0$ を満足することが 前提であるため注意が必要である。

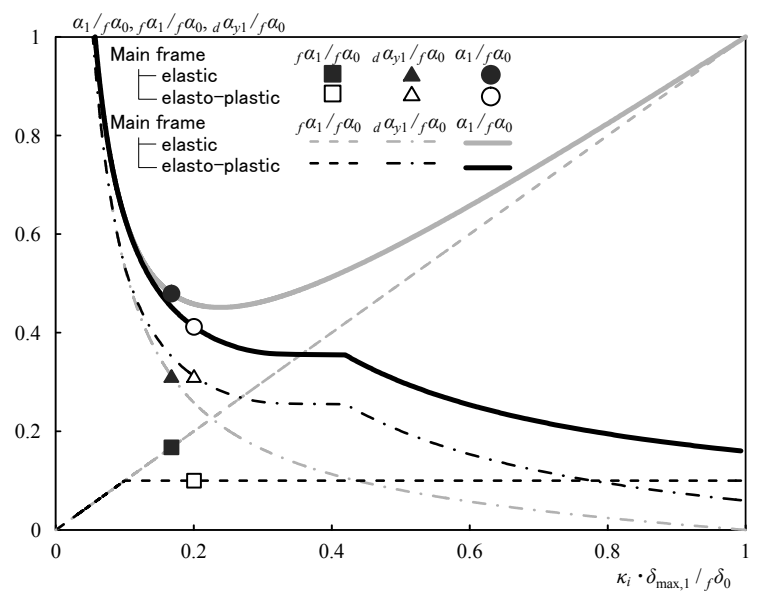

(a) $f \alpha_{v 1} / f \alpha_{0}=0.1$

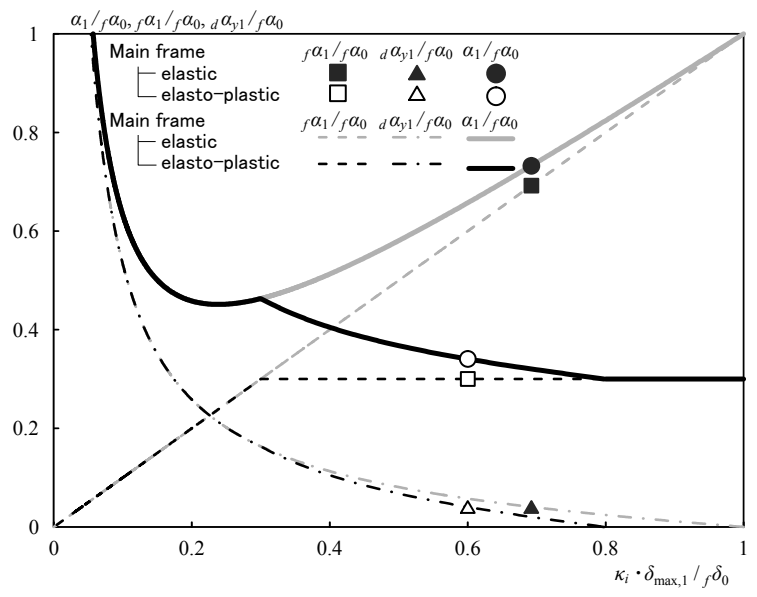

(b) ${ }_{f} \alpha_{y 1} /{ }_{f} \alpha_{0}=0.3$

Fig.9 Response curve of the first story with ${ }_{f} \alpha_{y 1} / f \alpha_{0}$ varied ${ }_{d} n_{e 1}=\mathbf{2 . 5}, \quad f n_{1}=1.0, \quad d \gamma_{1}=\mathbf{5 . 0}, f \gamma_{1}=4.0$

\section{3 主架構の等価繰返し数が応答に及ぼす影響}

本節では, 主架構の等価繰返し数 ${ }_{f} n_{1}$ を変動させ, 第 1 層の応答に 及ぼす影響を分析する。北村らは主架構が塑性化する場合の ${ }_{f} n_{1}$ を 1.0 にすることを提案している7)。本節では ${ }_{f} n_{1}$ を $0.4,1.4$ に変動させる。 ${ }_{f} n_{1}$ は主架構のエネルギー吸収効率を意味し,${ } n_{1}=0.4$ は主架構のエネ ルギー吸収効率が低い場合, $f n_{1}=1.4$ は主架構のエネルギー吸収効率 が高い場合に相当する。

Fig.10 に ${ }_{f} n_{1}$ を変動させた第 1 層の応答曲線を示す。Fig.10(a)のプ ロットに着目すると, 主架構が塑性化した場合に最大層間変形比 $\kappa_{1}$. $\delta_{\max , 1} /_{f} \delta_{0}$ が主架構弾性の場合より大きくなり, Fig.10(b)のプロット に着目すると, 主架構が塑性化した場合に $\kappa_{1} \cdot \delta_{\max , 1} / \delta_{f} \delta_{0}$ が主架構弾性 の場合より小さくなることがわかる。以上から， ${ }_{f} n_{1}$ を大きく想定す ると， $\kappa_{1} \cdot \delta_{\max , 1} / f \delta_{0}$ と全体架構のせん断力係数比 $\alpha_{1} / f \alpha_{0}$ を小さくす ることが可能であるが, 主架構がダンパーと同様に多数回の繰返しに よる損傷を許容していることと同意であり, 主架構の損傷が大きくな る。さらに, ${ }_{f} n_{1}$ はバラつきが大きいため ${ }^{7}$, 主架構のエネルギー吸収 を過度に期待した制振構造の設計は危険である。そのため, ${ }_{f} n_{1}$ は 1.0 程度とすることが望ましい。

\section{4 ダンパーの等価繰返し数が応答予測に及ぼす影響}

本節では，ダンパーの等価繰返し数 ${ }_{d} n_{e 1}$ を変動させ，第 1 層の応

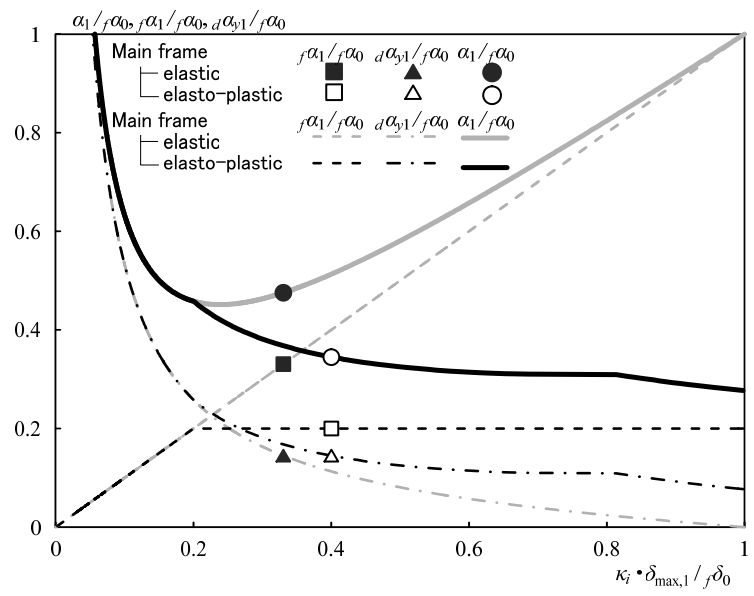

(a) ${ }_{f} n_{1}=0.4$

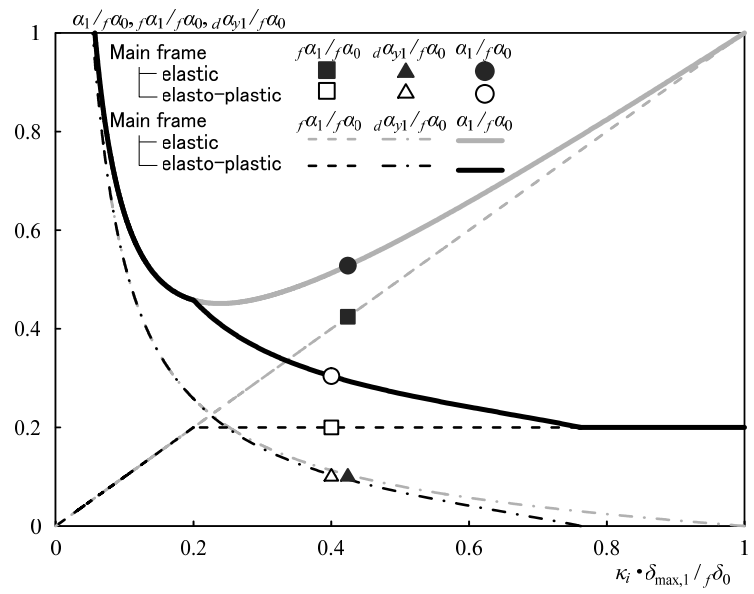

(b) ${ }_{f} n_{1}=1.4$

Fig.10 Response curve of the first story with ${ }_{f} \boldsymbol{n}_{1}$ varied ${ }_{f} \alpha_{y 1} /{ }_{f} \alpha_{0}=0.2, \quad d n_{e 1}=2.5, \quad d \gamma_{1}=5.0, \quad f \gamma_{1}=4.0$ 
答に及ぼす影響を分析する。 $d n_{e 1}$ は地震動の特性や応答レベルによっ てバラつきが大きい值である ${ }^{15), 16)}$ 。本節では ${ }_{d} n_{e 1}$ を $1.25,5.0$ に変動 させる。 $d n_{e 1}=1.25$ は継続時間の短い比較的短周期の地震動, $d n_{e 1}=$ 5.0 は継続時間の長い長周期の地震動を想定している。

Fig.11 に $d n_{e 1}$ を変動させた第 1 層の応答曲線を示す。Fig.11(a)の ${ }_{d} n_{e 1}=1.25$ に着目すると, 主架構が塑性化する場合で主架構の塑性変 形倍率 ${ }_{f} \mu_{i}^{\prime}$ が 1.0 となるダンパーの降伏せん断力係数比 ${ }_{d} \alpha_{y 1} /{ }_{f} \alpha_{0}$ が 0.2 程度であるのに対して Fig.11(b)の $d n_{e 1}=5.0$ では, $d \alpha_{y 1} /{ }_{f} \alpha_{0}$ は小 さく 0.05 程度となる。これは, $d_{e 1}$ が大きいのでダンパーが効率良く エネルギーを吸収しているためである。しかし， $d_{n} n_{e 1}$ を必要以上に大 きく設定すると制振効果を過大に評価することになる。 $d n_{e 1}$ は地震動 の特性や応答レベルに応じて適切な值を選ぶ必要がある99, 177, 18)。

\section{5 主架構の損傷分散係数が応答予測に及ぼす影響}

本節では, 主架構の損傷分散係数 $f \gamma_{1}$ を $2.5,8.0$ に変動させ, 応答 に及ぼす影響を分析する。 $f \gamma_{1}=2.5$ は第 1 層の主架構に過度に損傷 が集中寸る架構であり, $f \gamma_{1}=8.0$ は全層に概社均等に損傷が分散さ れる架構であることを意味する。

Fig.12 に $f_{f} \gamma_{1}$ を変動させた第 1 層の応答曲線を示す。Fig.13(a)の $f \gamma_{1}=2.5$ に着目すると, 主架構が塑性化した場合に最大層間変形比 $\kappa_{1} \cdot \delta_{\max , 1} /{ }_{f} \delta_{0}$ が主架構弾性の場合より大きくなる。一方, Fig.12(b)の

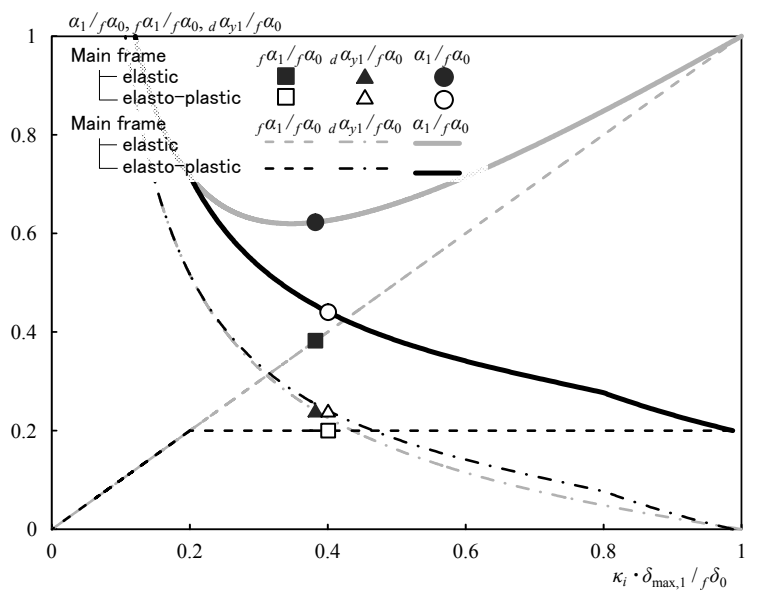

(a) ${ }_{d} n_{e 1}=1.25$

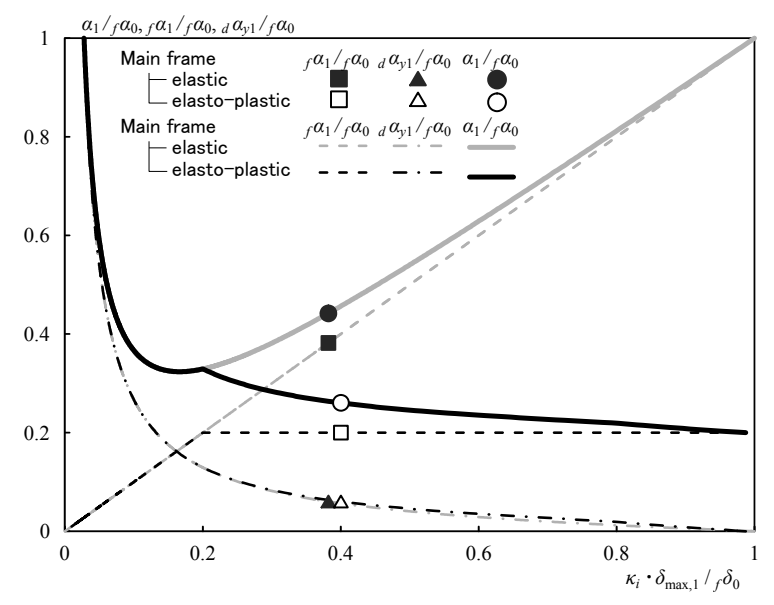

(b) $d n_{e 1}=5.0$

Fig.11 Response curve of the first story with ${ }_{d} \boldsymbol{n}_{e 1}$ varied ${ }_{f} \alpha_{y 1} /{ }_{f} \alpha_{0}=\mathbf{0 . 2},{ }_{f} \boldsymbol{n}_{1}=\mathbf{1 . 0},{ }_{d} \gamma_{1}=\mathbf{5 . 0},{ }_{f} \gamma_{1}=\mathbf{4 . 0}$
${ }_{f} \gamma_{1}=8.0$ に着目すると, 主架構が塑性化した場合の $\kappa_{1} \cdot \delta_{\max , 1} / f \delta_{0}$ が主 架構弾性の場合より小さいことがわかる。これは, Fig.12(a)，(b)とも に主架構の等価繰返し数を ${ }_{f} n_{1}=1.0$ と等しく設定しているためであ る。つまり, $f \gamma_{1}=2.5$ では第 1 層に集中したエネルギーを 1 サイクル で吸収しなければいけないため必然的に変形は増大する。逆に, $f \gamma_{1}$ を大きく設定すると, 変形 $\left(\kappa_{1} \cdot \delta_{\max , 1} /_{f} \delta_{0}\right)$ とせん断力 $\left(\alpha_{1} / f_{f} \alpha_{0}\right)$ を 小さくすることが可能である。従って, 全層に概ね均等に損傷を分散 する設計が望ましいといえる。

\section{6 ダンパーの損傷分散係数が応答予測に及ぼす影響}

本節では, ダンパーの損傷分散係数 $d \gamma_{1}$ を $2.5,8.0$ に変動させ, 第 1 層の応答に及ぼす影響を分析する。 $d \gamma_{1}=2.5$ は第 1 層の主架構に過 度に損傷が集中寸るダンパー配置であり,$d \gamma_{1}=8.0$ は全層に概ね均 等に損傷が分散される配置であることを意味する。

Fig. 13 に ${ }_{d} \gamma_{1}$ を変動させた第 1 層の応答曲線を示す。 6.5 節と同様 に, $d \gamma_{1}$ を大きく設定することで変形 $\left(\kappa_{1} \cdot \delta_{\max , 1} /_{f} \delta_{0}\right)$ とせん断力 $\left(\alpha_{1}\right.$ $\left.I_{f} \alpha_{0}\right)$ を小さくすることができるが， $d \gamma_{1}$ を大きく設定するにつれて 他層に損傷集中が生じる可能性が高くなるため, $\left[1 / d \gamma_{1}\right] \cdot N>2$ とな る值 ${ }^{14)}$ から全層で均一な損傷分布となる值の範囲 $\left(N / 2<{ }_{d} \gamma_{1}<N\right)$ に設定することが望しい。

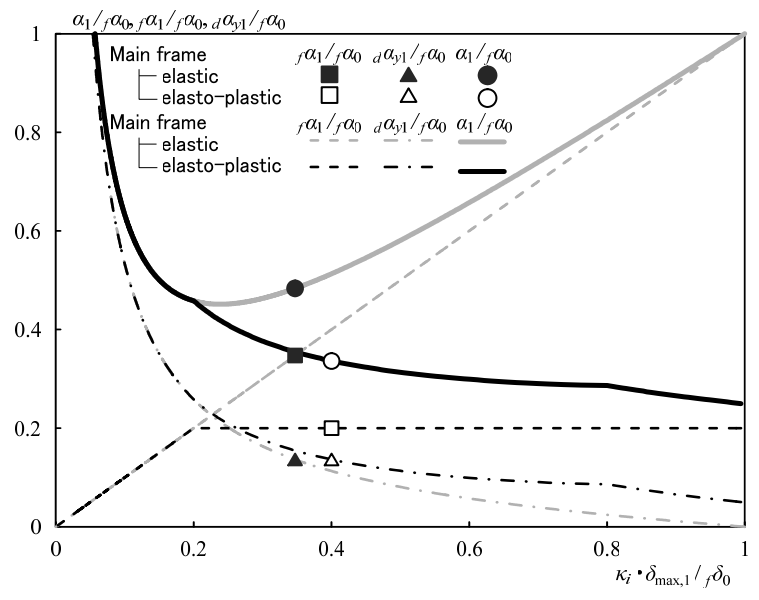

(a) $f \gamma_{1}=2.5$

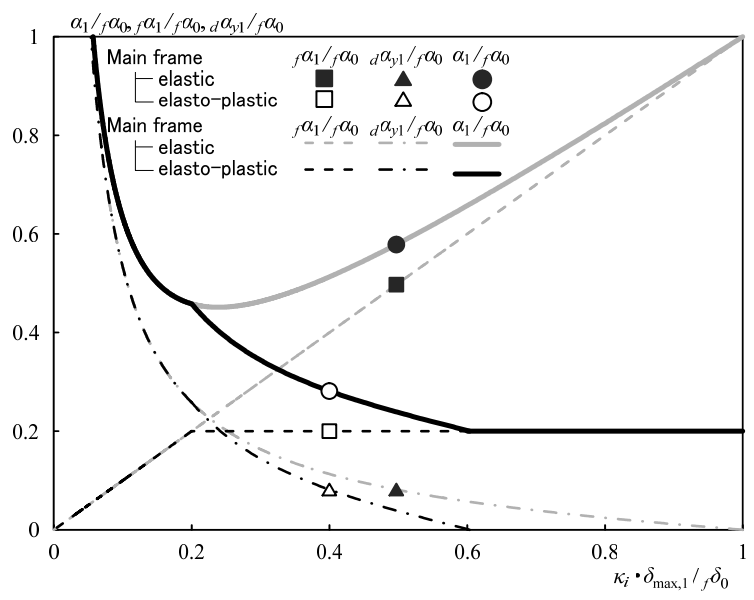

(b) ${ }_{f} \gamma_{1}=8.0$

Fig.12 Response curve of the first story with ${ }_{f} \boldsymbol{n}_{1}$ varied ${ }_{f} \alpha_{y 1} /{ }_{f} \alpha_{0}=0.2, \quad{ }_{d} n_{e 1}=2.5,{ }_{f} n_{1}=1.0, \quad d \gamma_{1}=\mathbf{5 . 0}$ 


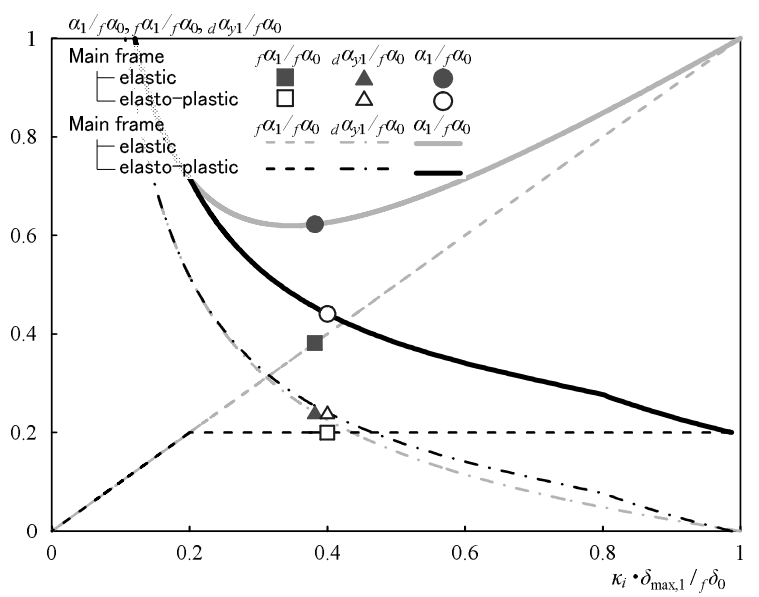

(a) ${ }_{d} \gamma_{1}=2.5$

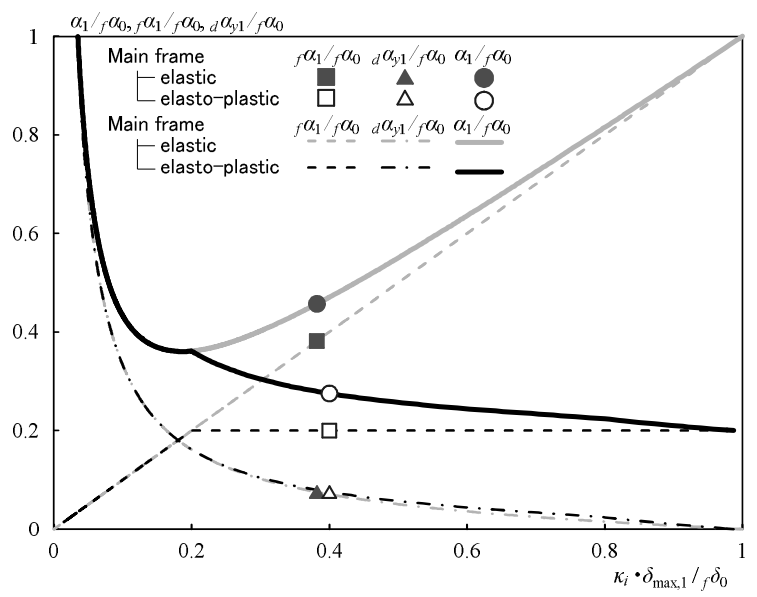

(b) ${ }_{d} \gamma_{1}=8.0$

Fig.13 Response curve of the first story with $d \gamma_{1}$ varied

$$
{ }_{f} \alpha_{y 1} /{ }_{f} \alpha_{0}=0.2,{ }_{d} n_{e 1}=2.5,{ }_{f} n_{1}=1.0, \quad{ }_{f} \gamma_{1}=4.0
$$

\section{7. まとめ}

本論文では, 履歴ダンパーを有する制振構造における, 主架構の塑 性化の程度を考慮したエネルギーの釣合に基づく第 1 層の応答予測 式の提案を行った。そして，予測された層間変形やせん断力を時刻歷 応答解析結果と比較して, 応答予測手法の妥当性を検証した。さらに, 応 答予測を行う際に重要となるパラメータが応答に及ぼす影響について 検討した。以下に得られた知見を示す。

(1) 提案した主架構の塑性化の程度に伴うダンパーの等価繰返し数の低 下率は, 部材モデルおよび多質点系等価せん断型モデルのダンパーの 等価繰返し数の傾向を捉えていることが確認できた。

(2) 主架構の塑性化の程度を考慮した第 1 層の応答予測手法を主架構の 降伏せん断力係数比, 主架構とダンパーの等価繰返し数および主架構 とダンパーの損傷分散係数を用いて導出し, 応答予測が時刻歴応答解 析結果に対応していることを確認した。

(3) 主架構の降伏せん断力係数比, 主架構とダンパーの等価繰返し数およ び主架構とダンパーの損傷分散係数を変動させた応答曲線を示した。 それらの值が応答に及ぼす影響を確認することができた。 なお，本論文では制振構造の応答を第 1 層に代表させ，その応答予測手法 を示したが，各層の応答予測については別報にて報告する予定である。

\section{謝辞}

本研究は, 新日鉄住金エンジニアリング株式会社, 東京理科大学北 村研究室, 東京工業大学佐藤研究室によるエネルギー法研究会の成果 の一部を用いたものです。特に, 東京理科大学 松田頼征助教, 新日 鉄住金エンジニアリング株式会社 綿貫雄太氏，山口慎吾氏には本論 文を執筆する上で貴重なご意見を賜りました。ここに記して感謝の意 を表します。

\section{参考文献}

1) Kitamura, H. , Kitamura, Y., Ito, M. and Sakamoto, M.: Analysis of The Present Situation of Response Control Systems in Japan Based on The Survey of Applied Buildings, AIJ Journal of Technology and Design, No.18, pp.55-60, 2003. 12 (in Japanese)

2) Architectural Institute of Japan: Protecting High-rises Against Long Period Motions - Wisdom to Share among Designers and Engineers, 2013.11 (in Japanese)

日本建築学会：長周期・長時間地震動と超高層建物の対応策-専門家とし て知っておきたいこと, 2013.11

3) Sato, D., Nagae, T., Ouchi, Y., Shimada, Y., Kitamura, H., Fukuyama, K., Kajiwara, K., Inoue, T., Nakashima, M., Saito, T. and Fukuwa, N.: E-Defense Shaking Table Tests on A Steel High-rise Building Retrofitted by Steel Dampers Against Long-Period Ground Motions, Journal of Structural and Construction Engineering (Transactions of AIJ), Vol.76, No.667, pp.1639-1648, 2011.9 (in Japanese)

4) Akiyama, H.: Earthquake-Resistant Design Method for Buildings Based on Energy Balance, Gihodo Shuppan, 1999.11 (in Japanese) 秋山宏：エネルギーの釣合に基づく建築物の耐震設計，第 1 版，技報堂 出版, 1999.11

5) Independent administrative agency Building Research Institute: Seismic SteelStructure Design Based on the Balance of Energy, Gihodo Shuppan, 2008.9 (in Japanese)

独立行政法人 建築研究所: 鋼構造建築物へのエネルギー法活用マニュ アルー 平成 17 年度国土交通省告示第 631 号「エネルギーの釣合に基づ く耐震計算法」に準拠して 一, 第 1 版, 技報堂出版, 2008.9

6) Wakita, N., Matsukage, T., Higuchi, K., and Nakamura, H.: Structural Design By Energy Balance-Based Seismic Resistant Design Introduction Of Design Realized Improvement Of Earthquake Performance And Economy , Nippon Steel Engineering Technical Report, Vol.3, 2012.1 (in Japanese)

脇田直弥，松蒢知明，樋口公平，中村秀司：エネルギー法による建物の 構造設計〜優れた耐震性と経済性を両立した設計手法の確立〜，新日鉄 エンジニアリング技報 Vol.3, 2012.1

7) Kitamura, H., Zaitsu, K. and Mayahara, T.: Energy Balance-based Seismic Response Prediction Method for Response Controlled Buildings Using Hysteresis Dampers, Journal of Structural and Construction Engineering (Transactions of AIJ), No.599, pp.71-78, 2006.1 (in Japanese)

8) Matsuzawa, Y., Sato, D., Kitamura, H., Yamaguchi, M., Wakita, N. and Matsukage, T.: Energy Balance-Based Seismic Response Evaluation Method for Passive Control System, Considering the Extent of Plastic Deformation in Mainframe, Summaries of Technical Papers of Annual Meeting, Architectural Institute of Japan, B-2, pp.1041-1042, 2013.8 (in Japanese)

松澤祐介，佐藤大樹．北村春幸，山口路夫，脇田直弥，松蒢知明：主架構 の塑性化の程度を考慮したエネルギーの釣合に基づく第 1 層の応答評価 法，日本建築学会大会学術講演梗概集, B-2,pp.1041-1042, 2013.8

9) Sato, D., Kitamura, H., Sato, D., Sato, T., Yamaguchi, M., Wakita, N. and Watanuki, Y.: Energy Balance-based Seismic Response Prediction Method for Response Control Structures with Hysteretic Dampers and Viscous Dampers, Journal of Structural and Construction Engineering (Transactions of AIJ), Vol.79, No.699, pp.631-640, 2014.5 (in Japanese)

10) Sato, D., Kasai, K. and Tamura, T.: Influence of Frequency Sensitivity of Viscoelastic Damper on Wind-Induced Response, Journal of Structural and Construction Engineering (Transactions of AIJ), Vol.74, No.635, pp.75-82, 2009.1 (in Japanese)

11) Kato, T., Sato, T., Sato, D., Kitamura, H., Nagae, T., Ishii, M. and Yoshie, K.: Study on Current Conditions of Existing High-rise Buildings and Construction 
of Seismic Analysis Model Based on Literature Survey, AIJ Journal of Technology and Design, Vol.20, No.45, pp.575-580, 2014.6 (in Japanese)

12) Tobari, R., Sato, D., Furuya, K., Kitamura, H., Ishii, M., Yoshie, K., Miyazaki, M., Sasaki, K. and Iwasaki, Y.: The Evaluation of the Vibration Control Performance of the Building with Hysteretic Damper using Frame Parameters for Control, Journal of Structural Engineering, Vol.59B, pp.321-327, 2013.3 (in Japanese)

13) Kuribayashi, K., Sato, D., Kitamura, H., Yamaguchi, M. and Nishimoto, K.: Energy Balance-based Seismic Response Prediction Method for Steel Structure Considering Effective Hysteretic Damper Deformation, Journal of Structural and Construction Engineering (Transactions of AIJ), Vol.76, No.661, pp.543552, 2011.3 (in Japanese)

14) Iwamori, T., Sato, D., Kitamura, H., Yamaguchi, M., Wakaita, N. and Watanuki, Y.: Prediction Accuracy of Cumulative Damage Distribution for Passive Controlled Structure with Hysteretic Dampers, Journal of Structural Engineering, Vol.63B, pp.295-301, 2017.3 (in Japanese)

15) Narita S., Oana A., Kitamura H., Sato T., Sato D., Sato T. and Dan K.: Reevaluation of f-Values of Long-Period Ground Motions and Equivalent Number of Repetitions of Single Elemental Earthquake Based on the Elasto-Plastic Response Analysis, Summaries of Technical Papers of Annual Meeting, Architectural Institute of Japan, B-2, pp.717-718, 2016.8 (in Japanese) 成田冴子, 小穴温子, 北村春幸, 佐藤利昭, 佐藤大樹, 佐藤俊明, 壇一男, 吉江慶祐, 谷内孝誠; 長周期地震動における $f$ 值と単位地震動の等価 繰り返し数の弾塑性応答解析に基づく再評価, 日本建築学会大会学術講 演梗概集, B-2, pp.717-718, 2016.8

16) Narita S., Sato D., Oana A., Kitamura H., Matsuda Y., Sato T. and Dan K.: Comparison between the Equivalent Repetition Number at Maximum Response Occurrence Time and That at Earthquake End Time and its Validation, Summaries of Technical Papers of Annual Meeting, Architectural Institute of Japan, B-2, pp.149-150, 2017.8 (in Japanese)

成田讶子，佐藤大樹，小穴温子，北村春幸，松田頼征，佐藤俊明，壇一 男: 最大応答発生時刻と地震終了時刻の等価繰り返し数の比較とその 検証, 日本建築学会大会学術講演梗概集, B-2,pp.149-150, 2017.8

17) Akiyama, H. and Kitamura, H.: Relationship between Energy Spectra and Velocity Response Spectra, Journal of Structural and Construction Engineering (Transactions of AIJ), No.608, pp.37-43, 2006.10 (in Japanese)

18) Oana, A., Kitamura, H., Yoshie, K. and Sato, T.: Qualitative Evaluation of Longperiod Ground Motions for Design Earthquake Motions, Journal of Structural and Construction Engineering (Transactions of AIJ), Vol.77, No.674, pp.575584, 2012.4 (in Japanese)

19) Kitamura, H.: Seismic Response Analysis Methods for Performance Based Design, Shokoku-sha, 2009.4 (in Japanese)

北村春幸：性能設計のための建築振動解析入門，第 2 版，彰国社, 2009.4

\section{附録 A 応答予測式の収斂計算}

Fig.A は横軸に収斂計算の回数, 縦軸に $\delta_{\max , 1^{(j)}}$ と $\delta_{\max , 1}{ }^{(j-1)}$ の誤差を示す。Fig.A より, 収斂計算はいずれのケースにおいても 5 回程度行うことで $\delta_{\max , 1} 1^{(j)}$ と $\delta_{\max , 1}^{(j-1)}$ の誤差が $10 \%$ 以内に収まっていることがわかる。

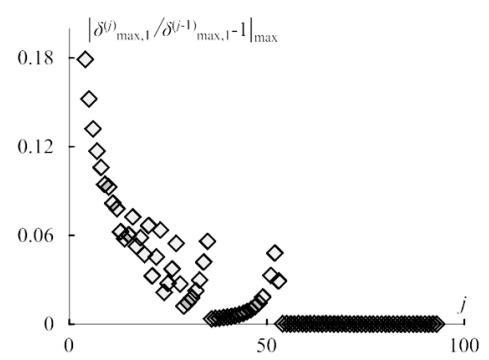

Fig.A Error of $\delta_{\max 1}^{(j)}$ and $\delta_{\max 1}^{(j-1)} \quad\left(N=10,{ }_{f 1} T=1.0\right)$

附録 B 応答予測手順のフロー

Fig.B に応答予測手順のフローを示す。ただし，以下の条件 ${ }^{14)}$ が成り立つも のとする。

・最大損傷集中 $\left[1 / d \gamma_{i}\right]_{c, \text { max }}$ に質点数 $N$ を乗じた值は 2 以下

・第 1 層の最大応答值は $\kappa_{1} \cdot \delta_{\max , 1} /{ }_{f} \delta_{0}<2 \cdot{ }_{f} \alpha_{1} / f \alpha_{0}$

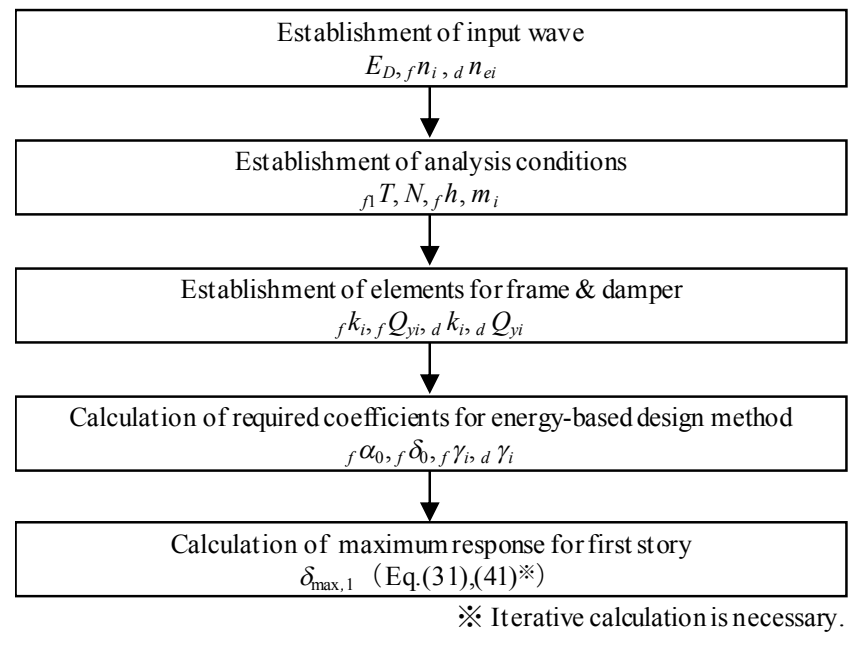

Fig.B Flow diagram of response prediction procedure

\section{附録 C 耐震構造の応答予測}

而震構造の応答予測式 ${ }^{19)}$ と, 本論文で提案する主架構の塑性化の程度を考慮

した応答予測式との関係を示す。

耐震構造の $t=t_{m}$ のときのエネルギーの釣合式は次式で表される。

${ }_{S} W_{e}\left(t_{m}\right)+{ }_{S} W_{p}\left(t_{m}\right)=E_{D}\left(t_{0}\right)$

ここで, $s W_{e}$ : 耐震構造の弾性振動エネルギー, $s W_{p}$ : 耐震構造の累積塑性ひず みエネルギーである。

耐震構造の第 1 層の最大層間変形比は次式のように表される。

$\kappa_{1} \frac{\delta_{\operatorname{maxl}}}{f \delta_{0}}=\frac{\kappa}{8 \cdot s \gamma_{1} \cdot s n_{1}} \cdot\left(\frac{f \alpha_{0}}{s \alpha_{y 1}}-\frac{s \alpha_{y 1}}{f \alpha_{0}}\right)+\frac{s \alpha_{y 1}}{f \alpha_{0}}$

ここで, $s \gamma_{1}$ : 耐震構造の損傷分散係数, $s n_{1}$ : 耐震構造の等価繰返し数, $s \alpha_{y 1}$ : 而震構造の降伏せん断力係数である。

Fig.C に耐震構造の応答曲線を示す。ダンパー量 $d \alpha_{y 1}$ が 0 になる点（最大層 間変形比 $\kappa_{1} \cdot \delta_{\max , 1} I_{f} \delta_{0}=1.0$ ） で耐震構造の応答予測（図中灰色の二点鎖線） と本論文で提案する制振構造の全体架構の応答予測（図中黒色の実線）が一致 することが確認できる。

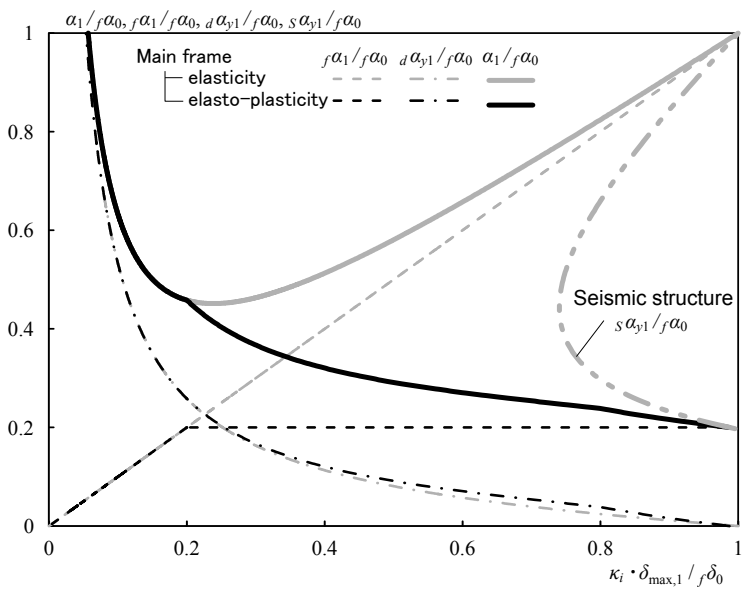

Fig.C Response curve of the first layer with Seismic Structure

$f \alpha_{y 1} / f \alpha_{0}=0.2, \quad d n_{e 1}=2.5, \quad d \gamma_{1}=5.0, \quad f n_{1}=1.0, \quad f \gamma_{1}=4.1$, $s n_{1}=1.0, s \gamma_{1}=4.1$ 


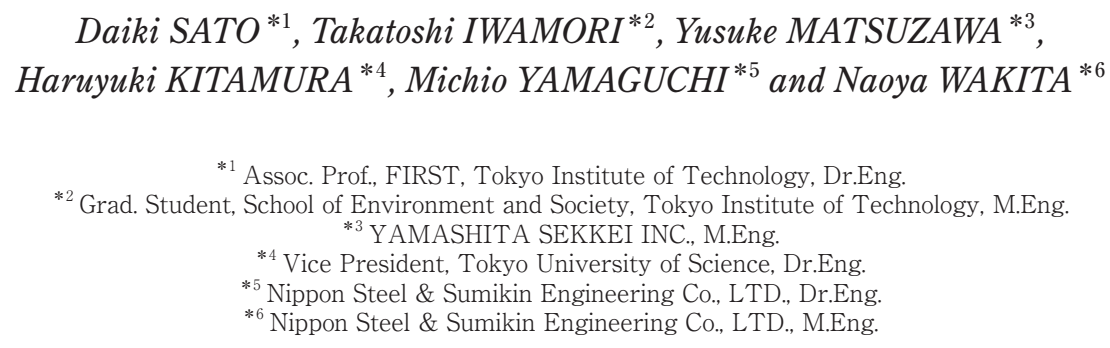

An ideal design of a passive controlled building is that its mainframe maintains its elasticity when subjected to ground motions. However, it is necessary to consider the plastic behavior of the mainframe of passive control building when designing for there might be seismic ground motions exceeding the assumptions. Additionally, it is necessary to evaluate the accumulated damage of the damper from several repetitive oscillations when long-period and long-duration ground motion occurred.

In one of the seismic structural design methods, there is an energy balance-based design method for earthquake-induced response of building that was proposed. This method can judge earthquake resistance of building handily and its general situation, and is very useful for evaluating the cumulative damage of mainframe and dampers. However, this energy balance-based design method assumes great transformation that may result to excessive response evaluation when the building mainframe is slightly plastic or has small plastic deformation - for example, response of a passive controlled building with hysteretic dampers.

This paper, therefore, proposes an energy balance-based response prediction method considering the extent of plastic deformation of the mainframe of the passive controlled building with hysteretic dampers. Chapter 2 presents the proposed reduction rates of the number of equivalent repetitions for dampers according to the extent of plasticity of the mainframe. Chapter 3 discusses the prediction method of the maximum story drifts considering the extent of plasticity of the mainframe is proposed. Chapter 4 examines the validity of the proposed method by comparing it with the time history analysis. Chapter 5 clarifies the effect of the number of equivalent repetition, damage dispersion coefficient and the yield shear force of the mainframe on the evaluation of the maximum response value.

The findings obtained are shown below.

(1) It is confirmed that the proposed reduction rate of the number of equivalent repetition for the damper due to the extent of plasticity of the mainframe roughly agrees with the results obtained from the time history analysis.

(2) The response prediction method of the first story considering the degree of plasticity of the building mainframe is derived using the yield shear force coefficient ratio of the building mainframe, the number of equivalent repetition for the mainframe and damper, and the damage distribution coefficient of the mainframe and damper. It is confirmed that this proposed response prediction method corresponds to the result of the time history response analysis.

(3) Various response evaluation curves in which the yield shear force coefficient ratio of the mainframe, the number of equivalent repetition for the mainframe and damper, and the damage distribution coefficient of the mainframe and damper are presented in this paper. This study verifies the influence of these parameters exerted on the response. 